Provided for non-commercial research and education use. Not for reproduction, distribution or commercial use.

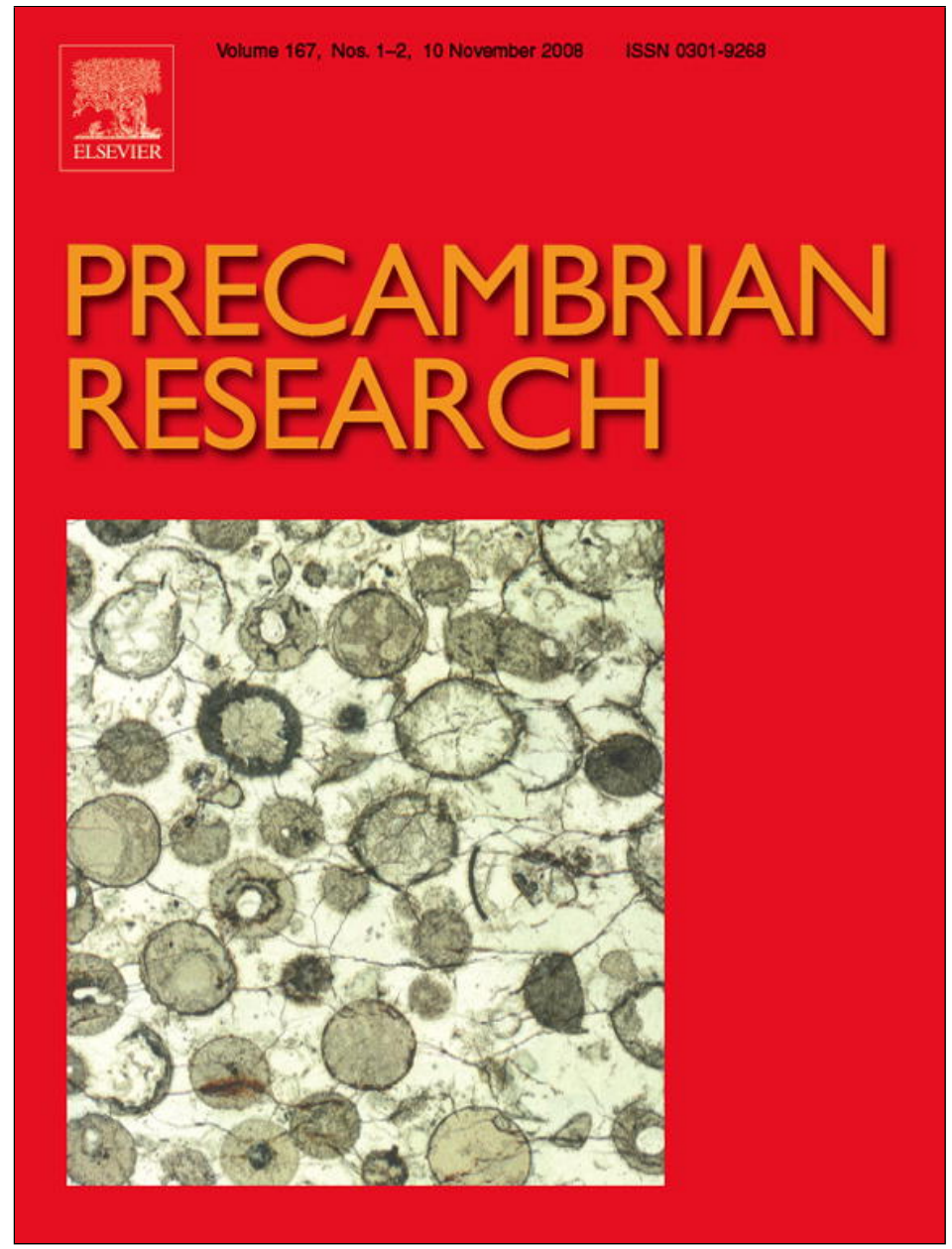

This article appeared in a journal published by Elsevier. The attached copy is furnished to the author for internal non-commercial research and education use, including for instruction at the authors institution and sharing with colleagues.

Other uses, including reproduction and distribution, or selling or licensing copies, or posting to personal, institutional or third party websites are prohibited.

In most cases authors are permitted to post their version of the article (e.g. in Word or Tex form) to their personal website or institutional repository. Authors requiring further information regarding Elsevier's archiving and manuscript policies are encouraged to visit:

http://www.elsevier.com/copyright 


\title{
New records of late Ediacaran microbiota from Poland
}

\author{
Małgorzata Moczydłowska* \\ Uppsala University, Department of Earth Sciences, Palaeobiology, Villavägen 16, SE 75236 Uppsala, Sweden
}

\section{A R T I C L E I N F O}

Article history:

Received 5 December 2007

Received in revised form 2 July 2008

Accepted 3 July 2008

\section{Keywords:}

Cyanobacteria

Phytoplankton

Acritarcha

Ediacaran

Habitats

Slushball Earth

\begin{abstract}
A B S T R A C T
New records of organic-walled microfossils, including cyanobacteria, phytoplankton (certain acritarchs) and some microbiota of unknown biological affinities, are reported from the late Ediacaran Włodawa Formation in the Łopiennik IG-1 borehole, Poland. The microfossil association consists mostly of known species, which originated prior to the Cryogenian Period, evidence that these microorganisms survived the Neoproterozoic glacial epochs. The longevity of most of the species is extended herein to ca. $545 \mathrm{Ma}$. One species is new but described as gen. et sp. indet., because only a single specimen is available. Although the microfossils represent both prokaryotic and eukaryotic groups of organisms, and benthic and planktic modes of life, all, with the exception of Valkyria, are photoautotrophic aerobes. Metabolic processes of nutrition, respiration and reproductive cycles, and ecologic habitats of these biota and the evolutionary lineages to which they belong are analyzed with respect to the basic requirements needed to survive prolonged periods of environmental perturbation.

All recorded here cyanobacteria are benthic microbial mat-dwellers, requiring ample water and regular oxygen supply and sun light for their metabolism. Planktic species of Leiosphaeridia studied here are considered to be green algae (chlorophyceans), forming resting cysts and alternating sexual/vegetative generations in their life cycle. They also required habitats of well-oxygenated open water in the photic zone and periodic access to bottom sediment (to rest the cyst) in order to survive the glacial epochs, as they evidently did. It is argued that the natural habitats of all these biota must have been preserved and ecologically functional throughout the Cryogenian Period, and have been robust enough to sustain viable populations and genetic stocks of at least some evolutionary lineages known at the time. This is a primary constraint imposed by contemporaneous marine biosphere on the Earth System model, which can be accepted among hypothetical versions of the Snowball Earth hypotheses based on sedimentological, geochemical, physical and other geological records. The Slushball Earth model, or comparable, is thus favoured over strict Snowball Earth model because it reconciles the habitable conditions with other envisaged geo- and physical conditions during the period.
\end{abstract}

(C) 2008 Elsevier B.V. All rights reserved.

\section{Introduction}

The Neoproterozoic Era, and especially its terminal Ediacaran Period, is characterised by restructuring of marine ecosystems due to changes in natural environments and rise of complexity in the biosphere. Shallow marine ecosystems, which have the best fossil record, have been affected by processes related to plate tectonics, transgressive and regressive cycles, weathering of continents, hydrosphere chemistry and oxygen content, hydrological cycle, and climatic fluctuations (Jenkins et al., 2004; Fike et al., 2006; Canfield et al., 2007). The biodiversity was increasing through time, albeit with periodic retardations, because of evolutionary innovations and the appearance of new clades of unicellular and metaphytic

\footnotetext{
* Tel.: +4618 47127 43; fax: +46184712591.

E-mail address: malgo.vidal@pal.uu.se.
}

taxa, and the metazoans (Gehling et al., 2000; Knoll, 2003; Grey, 2005; Peterson and Butterfield, 2005; Knoll et al., 2006; Xiao and Kaufman, 2006; Falkowski and Knoll, 2007; Vickers-Rich and Komarower, 2007).

The prokaryotic cyanobacteria have the longest (since Archean) and the most abundant (in Proterozoic) fossil record of the marine biota. Although being conservative in their evolution, as shown by long-ranging taxa and by simple morphology, they provide evidence of continuous and common occurrence of photosynthesising communities of bacterial mats and solitary species (Schopf, 1992, 1999). Their significance in recognising biodiversity and their role in marine ecosystems have been perhaps underestimated since the growing record and interest in evolutionarily more advanced and morphologically complex eukaryotic microbiota. The ecological adaptations of cyanobacteria and their life habitats are, however, indispensable as a source of information to assess the conditions that have existed through times of severe cli- 
matic and environmental changes, such as during the Cryogenian Period.

The eukaryotic microbiota of the Neoproterozoic were protoctists, both auto- and heterotrophic, and multicellular algae (Mankiewicz, 1992; Xiao, 2004; Knoll et al., 2006). During the Neoproterozoic they achieved higher evolutionary grades in morphology, metabolism and sexual reproduction, resulting in unprecedented diversity, and they began to diversify quickly, despite although being known since the Palaeoproterozoic. The eukaryotes thus developed new adaptations but also required more specific and stable environments for their advanced metabolism. They are obligatory/facultative aerobes, auto- and heterotrophes, and some have complex reproductive life cycles. In this respect, they are more vulnerable to changing ecological conditions and thus probably more critical for assessing global environmental extremes.

An association consisting of cyanobacterial, phytoplanktic algal and some microfossils of uncertain origin is described here from the terminal Ediacaran siliciclastic deposits of the Włodawa Formation in the Łopiennik IG-1 borehole, Poland (Fig. 1). The succession lies on the Lublin Slope of the East European Platform (EEP), which during the Cryogenian and Ediacaran times accumulated approximately $400 \mathrm{~m}$ thick strata of alternating sandstone and mudstone, and contains basaltic lavas and tuffs related to volcanism during the aborted rifting of the East European Craton (Fig. 2). The Ediacaran strata are in continuous sedimentological contact with the Cambrian and this entire transgressive sequence is fossiliferous. The Łopiennik succession is one of the best recognized in the area and has yielded acritarchs, cyanobacteria and vendotaenids, as well as trace fossils and skeletal faunas, including trilobites, that are utilized in biostratigraphic subdivision (Lendzion, 1983; Moczydłowska, 1991; Paczesna, 1996; Lendzion et al., 2008).

The microfossils studied belong to known species, except one gen. et sp. indet., and have well-recognized and long stratigraphic ranges (Fig. 3). With the exception of Valkyria borealis, they are palaeogeographically widespread. The significance of this new set of assemblages lies in the fact that it post-dates the Marinoan (=latest Cryogenian) glacial event. The compilation of global records of the species, extended by the occurrence on the Lublin Slope, indicates not only that they survived, but that their ecological environments were also preserved through the Cryogenian Period. This survival is a critical piece of evidence that is not compatible with strict version of the Snowball Earth hypothesis.

\section{Materials and methods}

The microfossil assemblage, consisting of cyanobacteria, spherical acritarchs (leiosphaerids) and some other organic-walled biota of uncertain taxonomic and systematic affiliations, derives from the lower Włodawa Formation in the Łopiennik IG-1 borehole (Fig. 2). The Ediacaran age of the major part of the formation is biostratigraphically and numerically well defined. The investigated interval of siliciclastic strata lies some $70-80 \mathrm{~m}$ below the Ediacaran-Cambrian boundary (Moczydłowska, 1991, 1999; Paczesna, 1996; Paczesna et al., 2008), and about $190 \mathrm{~m}$ above the volcanogenic Sławatycze Formation, the top of which has been isotopically dated in the neighbouring Kaplonosy IG-1 succession to $551 \pm 4 \mathrm{Ma}$ (Compston et al., 1995). The Kaplonosy IG-1 borehole is located only some $30 \mathrm{~km}$ from the Łopiennik IG-1, and its succession is a part of the same tectonically uninterrupted and sedimentologically uniform platformal unit including the same volcanic formation (Lendzion, 1983; Poprawa and Paczesna, 2002; Paczesna and Poprawa, 2005). The samples studied in detail here are from a depth of 5376.7, 5382.2, and $5385.6 \mathrm{~m}$, and have been selected because of the occurrence of well preserved and, tax- onomically, the most diverse microfossils within the Ediacaran interval. However, similar cyanobacteria and leiosphaerids have been recorded, although not described, from a total of 25 fossiliferous core samples from the Ediacaran strata of the Lublin and Włodawa formations in the Łopiennik IG-1 borehole, and in many more samples from other subsurface successions on the Lublin Slope of the EEP (Moczydłowska, 1991; Fig. 2).

The rock samples are from a continuously cored interval of alternating shales and sandstones containing phosphorite nodules. A standard processing technique has been used to extract and concentrate the organic matter with the primary purpose of isolating acritarchs (Moczydłowska, 1991) but it served equally well to yield cyanobacteria because of the use of a non-agitating method in the laboratory procedure. The maceration of the samples proceeded under carefully controlled laboratory conditions to prevent any chance of contamination. These conditions were sustained by filtered air ventilation and over-pressured air laminar out-flow system in the fume-hood, and filtered and de-ionized water used. The microfossils have been embedded in glycerol jelly strew mounts and examined under a transmitted light microscope with interference contrast (Leitz Wetzlar Dialux 29) and in high definition using a real-time 3D microscope (Edge R400). The light photomicrographs have been produced with immersion oil and interference contrast.

The microfossils, both planktic leiosphaerids and benthic cyanobacteria, are syngenetic with the sediment in which they are preserved. All microfossils display a similar state of preservation and the same degree of thermal maturation. Based on sedimentological and petrographic observations of the rock succession (Poprawa and Paczesna, 2002), it is clear that the sediments have never been re-deposited and thus the entombed in them microfossils.

\section{Geological setting, palaeoenvironments and age constraints}

The Łopiennik IG-1 borehole is located in southeastern Poland, on the Lublin Slope of the EEP, which in Ediacaran-Cambrian times constituted one margin of the East European Craton and Baltica palaeocontinent (Moczydłowska, 1991; Paczesna et al., 2008; Fig. 1). Baltica occupied high to intermediate palaeolatitudes in the southern hemisphere at around $30-60^{\circ}$, and the Lublin margin faced the Iapetus Ocean or its extension, the Tornquist Sea (Torsvik et al., 1996; Torsvik, 2003; Cocks and Torsvik, 2005). On the Lublin Slope, a marine siliciclastic sedimentary cover, initiated during the late Ediacaran marine transgression, lies on the $372 \mathrm{~m}$ thick volcanogenic rocks of the Sławatycze Formation (Fig. 2). The Sławatycze Formation, consisting of basalt, tuff, agglomerate and conglomerate, formed in an aborted rift at the margin of Baltica during the so-called Volhynian volcanic event at the end of the Neoproterozoic (prior to and at $551 \pm 4 \mathrm{Ma}$; Compston et al., 1995). The large volume of basalts was extruded in an extensive system of rift basins related to the opening of the Iapetus Ocean (Vidal and Moczydłowska, 1995). The underlying feldspathic and quartzitic continental sandstones of the Polesie Formation accumulated directly on the peneplained, early Proterozoic crystalline basement. The crystalline basement of the Lublin Slope has been isotopically dated to 2.0-1.4 Ga (Mansfeld et al., 1993).

The upper Ediacaran-Phanerozoic sedimentary succession on the Lublin Slope is almost horizontally lying, discontinuous and un-metamorphosed, attaining a maximum thickness of around $5600 \mathrm{~m}$ in the Łopiennik IG-1 borehole. The Łopiennik succession (Fig. 2) in its upper Ediacaran/Lower Cambrian portion is, however, a sedimentologically continuous, marine transgressive sequence 


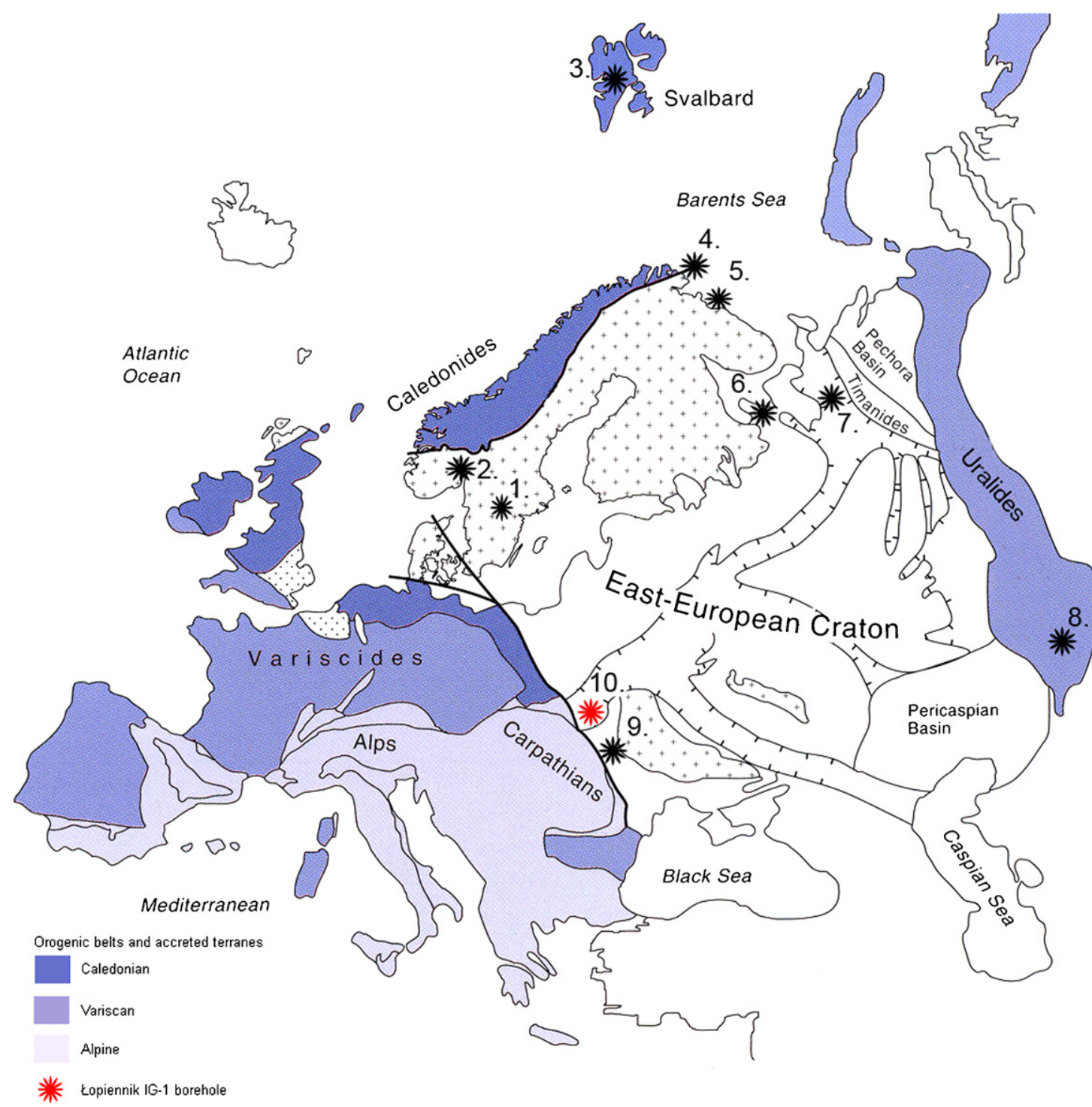

Fig. 1. Tectonic sketch-map of Europe and the North Atlantic area showing the extent of the Baltica palaeocontinent during the Neoproterozoic Era (shields are cross-patterned, rift grabens are stippled and platform shown by a white area around the East European Craton) and the distribution of microbial assemblages (asterisks). The coloured areas are fold-belts and terranes accreted subsequently to Baltica through the Phanerozoic in the Caledonian, Variscan and Alpine orogenies. The numbers 1-10 mark the location of the successions with microbial records: (1) Visingsö Group, Sweden; (2) Hedmark Group, Norway; (3) Akademikerbreen and Scotia groups, Svalbard; (4) Vadsø, Tanafjord, Vestertana and Barents Sea groups, Finnmark, Norway; (5) Kola Penninsula and Kildin Island, Russia; (6) White Sea coast, Russia; (7) Vychegda Formation, EEP, Russia; (8) South Urals and Bashkiria, Russia; (9) Mogilev-Podolski and Kanilov groups, the Ukraine; (10) Łopiennik IG-1 borehole on the Lublin Slope of the East European Platform, studied here (asterisk in red); complied from Vidal and Moczydłowska (1997) and Veis et al. (2006).

embracing the boundary between the two systems recognized on biostratigraphic grounds. The succession comprises quartzarenite of the Białopole Formation at its base, which is occasionally intercalated with mudstone and shale. The succeeding units are shale, mudstone and sandstone, which are interbedded and alternating, and predominantly shaley, attributed to the Lublin, Włodawa and Mazowsze formations. Overlying is a succession of quartz-rich sandstone with some intervals of alternating shale and sandstone of the Kaplonosy and Radzyn formations. The base of the Cambrian is defined in the uppermost part of the Włodawa Formation at a depth of $5306.7 \mathrm{~m}$, and it is supported by sound palaeontological evidence in this succession and on a regional scale (Moczydłowska, 1991, 1999; Paczesna, 1996; Paczesna et al., 2008; Lendzion et al., 2008). This evidence is provided by the first appearance of Cambrian acritarch species and trace fossils, including Trichophycus pedum, which is the index taxon for the base of the Cambrian (Landing, 1994; Geyer and Uchman, 1995).
The Ediacaran-Cambrian strata on the Lublin Slope have yielded rich associations of organic-walled microfossils (acritarchs, cyanobacteria and vendotaenids), trace fossils, soft-bodied and shelly metazoans (Lendzion, 1977, 1983; Moczydłowska and Vidal, 1986; Moczydłowska, 1991; Paczesna, 1986, 1996). The Cambrian lower boundary has been convincingly correlated with successions elsewhere on Baltica (Moczydłowska, 1991), with the Global Stratotype Section and Point of the base of Cambrian in Newfoundland, and with successions on other palaeocontinents (Moczydłowska, 1999, 2002; Vidal et al., 1999; Moczydłowska and Zang, 2006).

The upper Ediacaran succession on the Lublin Slope accumulated in near-shore and shallow open-marine environments on the platform shelf (Poprawa and Paczesna, 2002; Paczesna and Poprawa, 2005). The deposits of the Białopole Formation and its lateral and time equivalent Siemiatycze Formation are interpreted to be transitional, and changing vertically, from alluvial to near-shore marine. The Siemiatycze Formation extending on-land is predomi- 


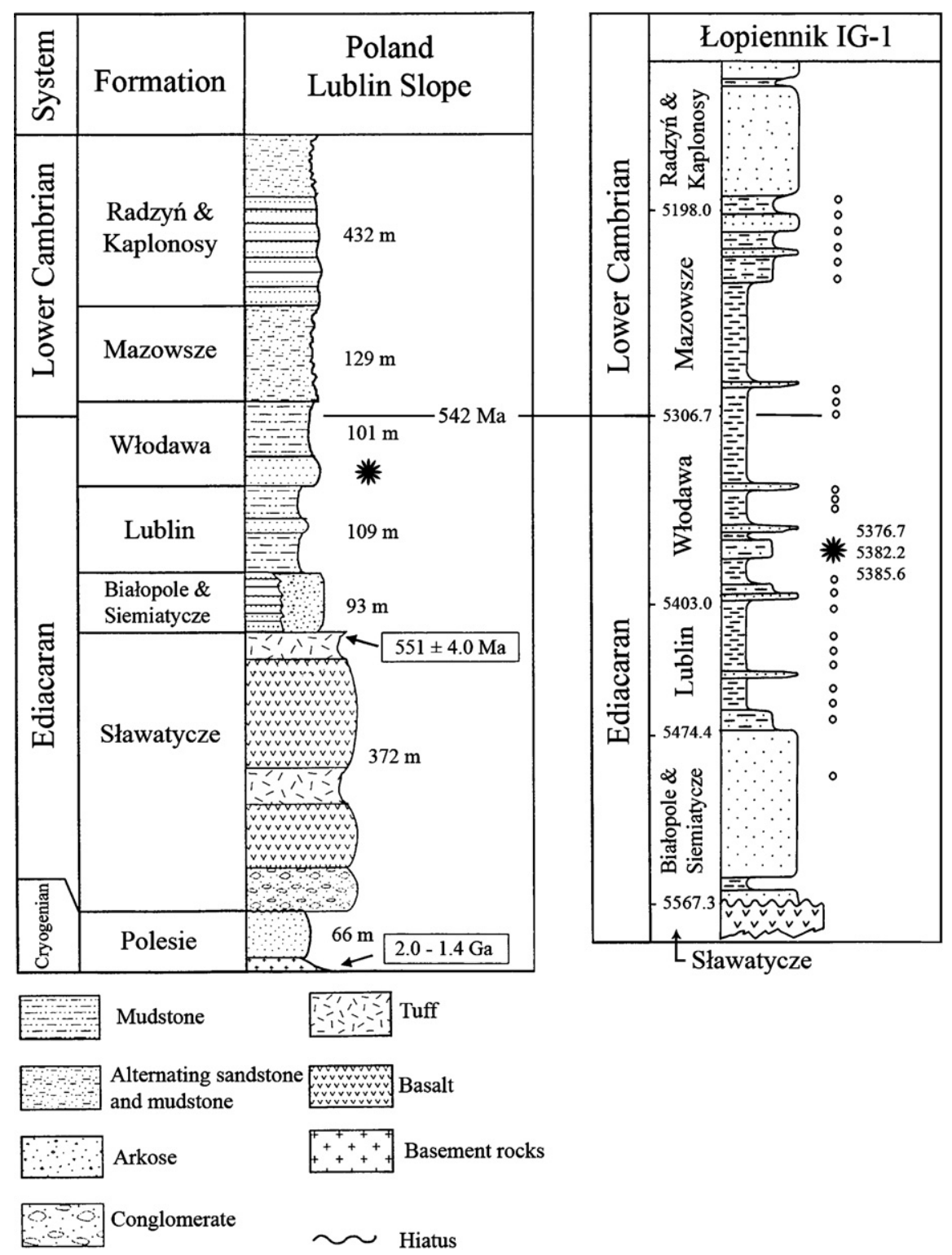

Fig. 2. Simplified Ediacaran-lower Cambrian lithostratigraphic succession on the Lublin Slope of the East European Platform in Poland, and the studied succession in the Łopiennik IG-1 borehole. Asterisks mark the stratigraphic level of microbiota described with a depth of the samples. The symbol of circles in the Łopiennik succession shows the occurrence of similar microfossils. Modified after Moczydłowska (1991). The isotopic ages are according to Compston et al. (1995). The base of the Cambrian Period at $542 \mathrm{Ma}$ is according to Gradstein et al. (2004).

nantly continental. The Białopole Formation represents lagoonal to coastal marine facies of an embayment, with tidal flat, channels and shore-face environments (see summary by Moczydłowska, 1991; Poprawa and Paczesna, 2002). The Lublin and Włodawa formations developed in entirely marine facies of the tidal flats and shallow shelf. The characteristic marine fossils of cyanobacteria and vendotaenids appear in the Białopole Formation (Moczydłowska, 1991), whereas the lowermost occurrence of trace fossils is in the Lublin Formation (Paczesna, 1996; Paczesna et al., 2008). In summary, the upper Ediacaran sediments represent an initial marine transgressive sequence (Paczesna and Poprawa, 2005), indicating brackish to open-marine, tidally influenced shallow marine shelf facies.

In the context of depositional environments of the Włodawa Formation (tidal flats to tidally influenced shallow shelf) and the natural habitats of the microorganisms contained, their burial is consistent with in situ occurrence. Acritarchs have settled from the "marine snow" suspended in the water column, and accumulated together with cyanobacteria, which were probably fragmented from the near-shore bacterial mats and colonies and transported a short distance by water currents to a burial site. In the interval of 5361.0-5370.0 m, lying a few metres above the studied interval, the benthic vendotaenid Tyrasotaenia sp., and benthic metazoans Sabellidites cambriensis and Onuphionella agglutinata occur (Lendzion, 1977; Moczydłowska, 1991). This suggests, together with sedimentological evidence (Poprawa and Paczesna, 2002; Paczesna and Poprawa, 2005), a stable and continuous existence of shallow marine environments, which became colonized through time by more diverse benthic organisms.

The maximum age of the late Ediacaran sedimentary succession in the Łopiennik borehole is constrained by isotopic dating of tuff layer at the top of the Sławatycze Formation in the Kaplonosy IG-1 borehole, which is closely located only some $30 \mathrm{~km}$ from the Łopiennik IG-1 borehole. Both successions are similar and accurately correlated by bio- and lithostratigraphy and by geo- 


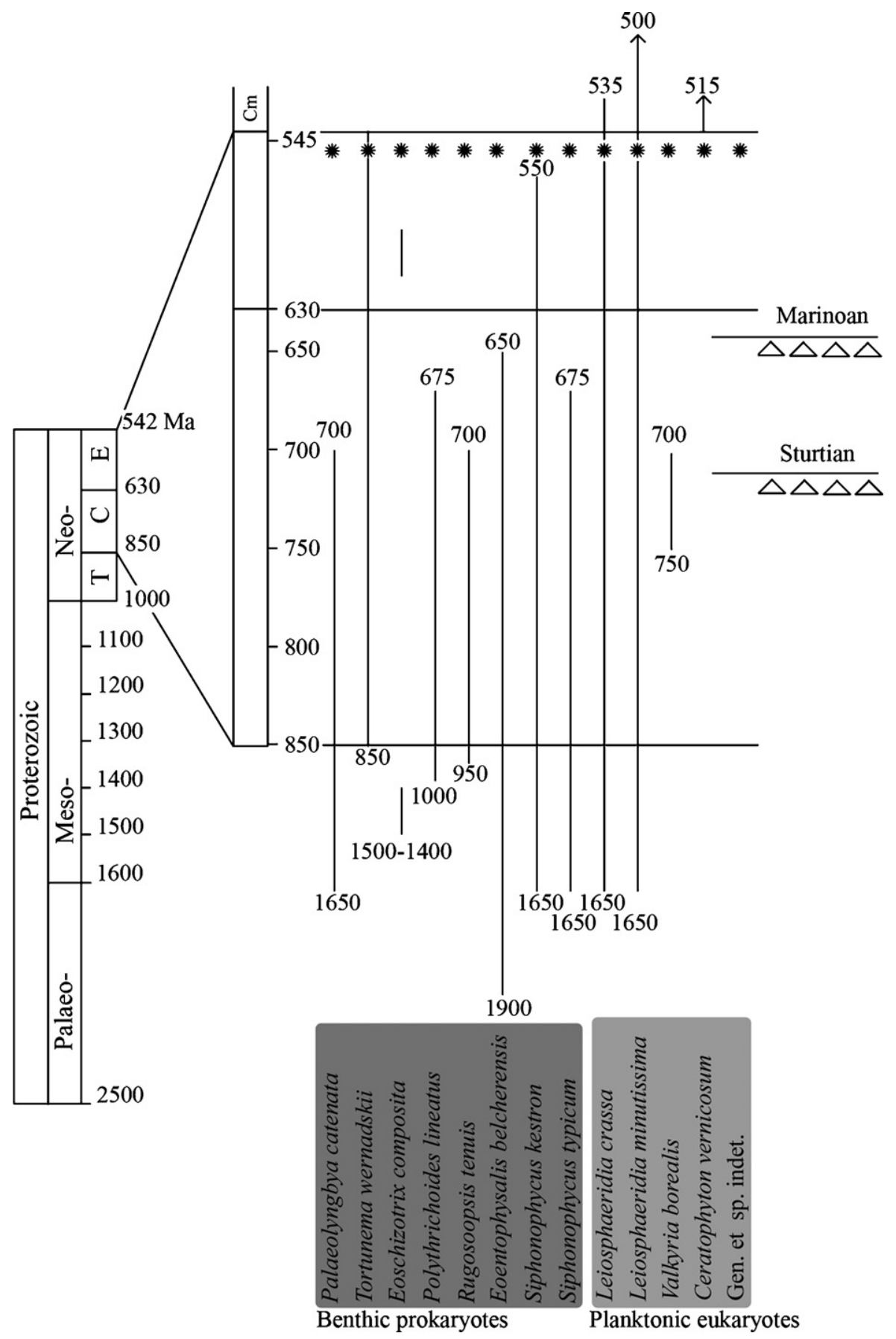

Fig. 3. Range chart of microfossil species recorded in the Łopiennik IG-1 succession compiled from global records and their approximate isotopic ages (various references). The symbol of asterisk indicates the present record; the symbol of triangle marks the chronostratigraphic level of the Sturtian (720-710 Ma) and Marinoan (650-635 Ma) glaciations (isotopic ages according to Halverson, 2006). Abbreviations refer to as: T to the Tonian Period, C Cryogenian, E Ediacaran, Cm Cambrian.

physical logging. This age of $551 \pm 4 \mathrm{Ma}$ has been determined by $\mathrm{U}-\mathrm{Pb}$ on zircon by ion microprobe (Compston et al., 1995; Fig. 2).

The time interval between $542 \mathrm{Ma}$, the age of the beginning of Cambrian (Gradstein et al., 2004), and $551 \pm 4 \mathrm{Ma}$, which slightly preceded the beginning of the marine transgression on the Lublin Slope, spans the deposition of the uppermost Ediacaran sediments in the area and the succession studied (Fig. 2). This interval is ca. 5-13 Ma. It has been argued, based on sedimentological observations in the Kaplonosy IG-1 borehole that the upper most tuffs of the Sławatycze Formation grade continuously into the overlying mudstone at the base of the Białopole Formation (Vidal and Moczydłowska, 1995). Although the tuff layer is missing in the Łopiennik IG-1 borehole, which shows a hiatus at this point, this could be due only to a short-lasting event of non-deposition or erosion, because the successions are otherwise very similar, as mentioned above. Thus the sequence of the Ediacaran strata on the Lublin Slope records a depositional history of ca. 5-13 Ma. The rate of sedimentation interpolated from the maximum thickness of deposits (260 m; Fig. 2) and the time span involved suggests that the sampled strata may have been deposited approximately at $545 \mathrm{Ma}$. This is the inferred approximate age of the microfossil assemblage, 
although it is only complementary to the fossil evidence that has proved its latest Ediacaran relative age (see above).

\section{Preservation of microfossils}

The microfossils are well preserved, occasionally threedimensionally and, in the case of some cyanobacteria, with cell content in trichomes, but are thermally altered as shown by a dark colouration of the organic walls. Sphaeromorphic acritarchs, attributed to the genus Leiosphaeridia and interpreted as phytoplankton (see below), are numerous, thick- and thin-walled, three-dimensionally preserved or flattened, and in a wide range of dimensions.

The filamentous cyanobacteria are preserved as empty sheaths and entire trichomes, The trichomes are observed in various states of preservation, displaying tubular external sheaths with cells inside, which remain in chains or are taphonomically disconnected, or are partly empty (Figs. 4 and 5). The external sheaths are segmented, non-segmented, ornamented with thickenings or smooth, or tube-in-tube structures (Fig. 6). The cell units in trichomes show the internal structure of cytoplasm or shrivelled amorphous organic matter remains, or are empty inside. Filamentous cyanobacteria
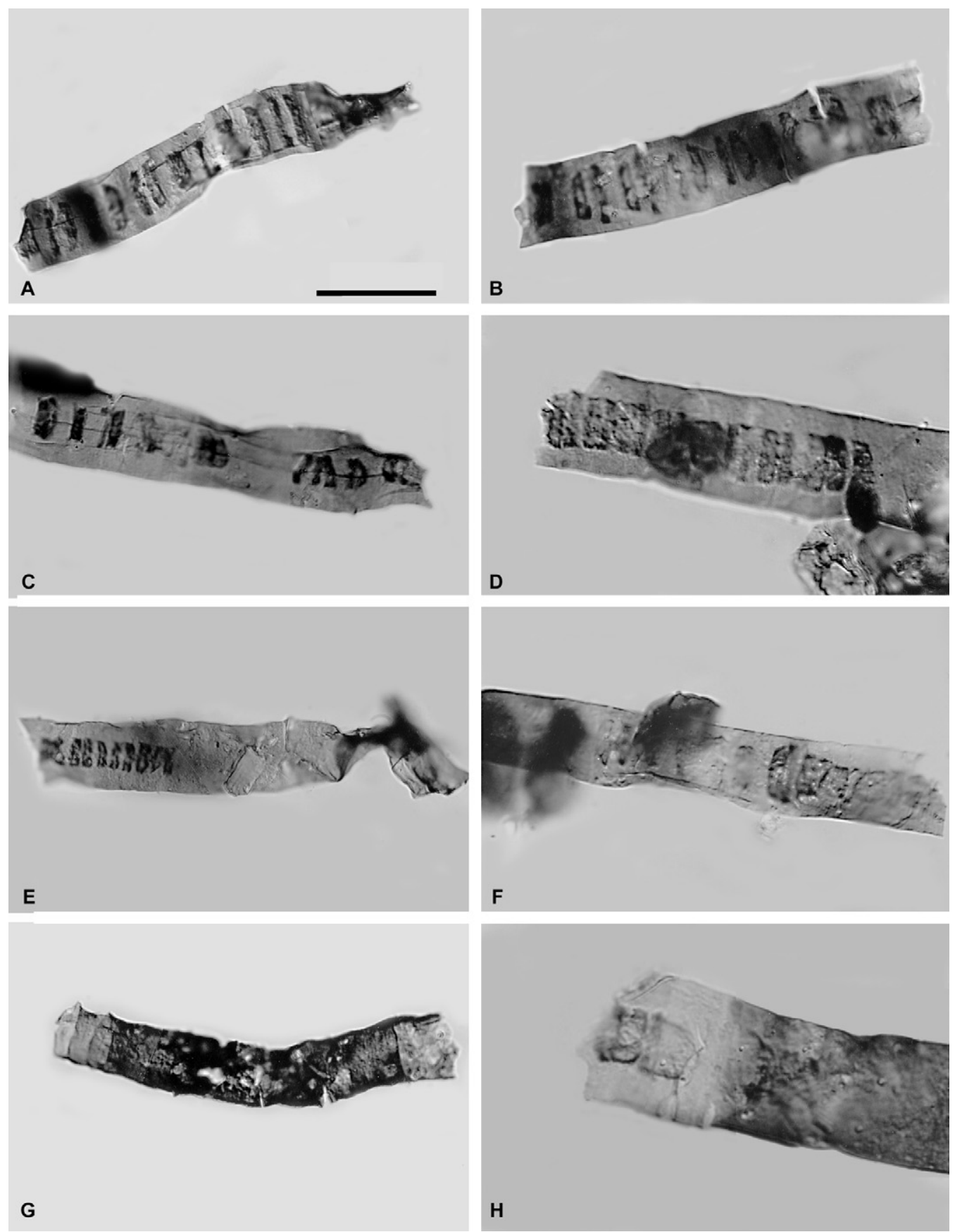

Fig. 4. (A-F, H) Palaeolyngbya catenata Hermann (1974). Sample from a depth of $5385.6 \mathrm{~m}$. Cyanobacterial trichomes consisting of non-septate sheaths with chain of cells inside at various states of being disconnected. (A) Specimen ME-Pl-05/1.M/40/3. (B) Specimen ME-Pl-05/1.H/29/1. (C) Specimen ME-Pl-05/1.E/49/1. (D) Specimen ME-Pl05/1.D/35. (E) Specimen ME-Pl-05/1.G/42/3. (F) Specimen ME-Pl-05/1.F/37. (H) Specimen ME-Pl-05/1.M/46/1. (G) Siphonophycus kestron Schopf (1968). Empty tubular and smooth sheath. Specimen ME-Pl-05/1. L/42. Scale bar in A equals $10 \mu \mathrm{m}$ for a A-E and G; $20 \mu \mathrm{m}$ for D and H. All specimens in this and following figures derive from the Łopiennik IG-1 borehole on the Lublin Slope of the EEP in Poland, and are of the latest Ediacaran age. 

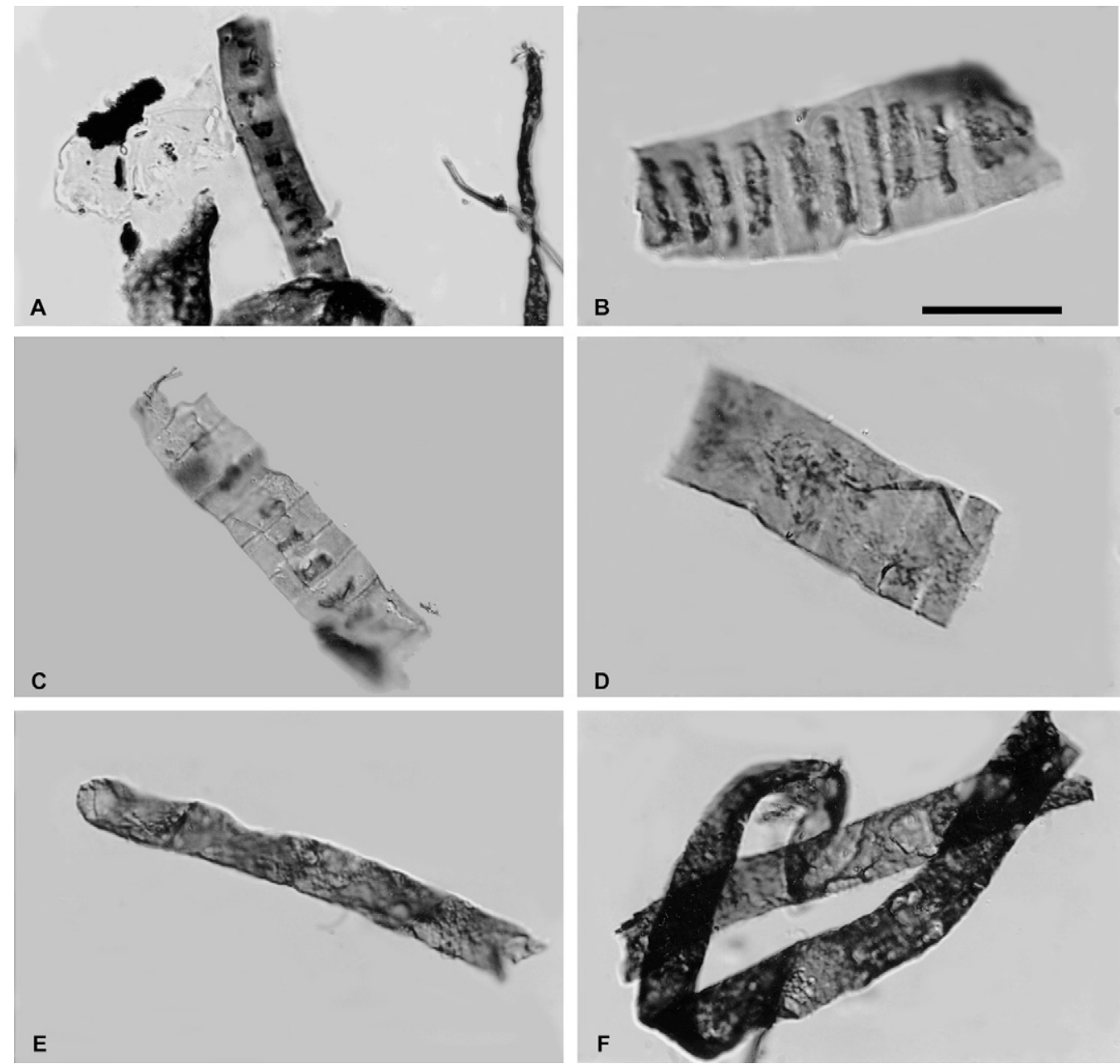

Fig. 5. (A-C) Palaeolyngbya catenata Hermann (1974). Sample from a depth of $5385.6 \mathrm{~m}$. Trichomes with sheaths showing initial state of segmentation on cell-units (A and B) and fully septate (C), with cells separated and inside of each cell-unit of the sheath. (A) Specimen ME-Pl-05/1.K/47/2. (B) Specimen ME-Pl-05/1.J/38/2. (C) Specimen ME-Pl-05/1.M/47/1. (D) Tortunema wernadskii (Shepeleva, 1960) Butterfield, 1994. Specimen ME-Pl-05/1J/47/3. Initial state of taphonomic dismembering of the cell-units of the empty pseudoseptate sheath. (E) Siphonophycus typicum (Hermann, 1974) Butterfield, 1994. Specimen ME-Pl-05/1.X/39/1. Empty sheath with rounded termination preserved. (G) Siphonophycus kestron Schopf, 1968. Specimen ME-Pl-05/1.N/43/2. Long and folded fragment of the empty sheath. Scale bar in B equals $40 \mu \mathrm{m}$ for A; $25 \mu \mathrm{m}$ for C; $20 \mu \mathrm{m}$ for B, D, E and F.

are preserved as individual specimens, in bundles (Fig. 7E) or as entangled colonies (Fig. 7F).

The coccoidal cyanobacteria occur as solitary cells, or in clusters and/or colonies.

The clusters of cells, enveloped by external organic sheaths (Eoenthophysalis, Fig. 7C) or occurring as diads, triads and tetrads of cells (Fig. 7D), are preserved in natural colonies. They are also seen in irregular fragments of bacterial mats.

All the described here cyanobacteria are benthic and associated with growth in bacterial mats, occurring in tidally influenced, predominantly subtidal to intertidal, marine environments of mostly carbonate platforms and in coastal salt flats, i.e. sabkha, environments (Hofmann, 1976; Golubic and Hofmann, 1976; Knoll et al., 1991; Butterfield et al., 1994; Sergeev et al., 1995; Golubic, 1999a,b). The same taxa are also known from the entirely siliciclastic sediments of the pre-Cryogenian Svanbergfjellet Formation (Butterfield et al., 1994) where their preservation, taxonomic diversity and host sediment natures, are comparable to the present record. The depositional setting of the sampled sediments is within a shallow marine shelf, tidally influenced and below the reach of tides (Poprawa and Paczesna, 2002; see below). This environment differs slightly from typical coastal inter- and supratidal occurrences of cyanobacterial mats, both recent and from the geological record. Because of this difference and because the present cyanobacteria are preserved mostly as solitary specimens, it seems that they were ripped-up from indigenous growth sites and transported from a coastal zone to a slightly offshore shelf before deposition. The good state of preservation of these microfossils indicates, however, that water current transport was for a short distance only, under relatively low energy and without any significant turbulence within the same basin soon after they had been swept away from their life habitat.

Planktic leiosphaerids accumulated from suspension in the water column in great numbers and exhibit an excellent state of preservation. They were buried together with the cyanobacteria. The same degree of thermal alteration and similar state of preservation displayed by benthic cyanobacteria and planktic acritarchs are in accord with an in situ burial after accumulation on the seafloor.

The thermal alteration of microfossils and particulate organic matter in the succession is due to burial of the deposits to a depth of at least $5500 \mathrm{~m}$ (observed today but presumably even deeper at some time in the past) and the temperature induced by geothermal gradient (Moczydłowska, 1988). The stage of lithogenesis of the Włodawa Formation in the Łopiennik succession corresponds to mesocatagenesis, which is indicated by the colour of the organic matter of microfossils, and the inferred palaeotemperature is in the range of $100-200^{\circ} \mathrm{C}$. 


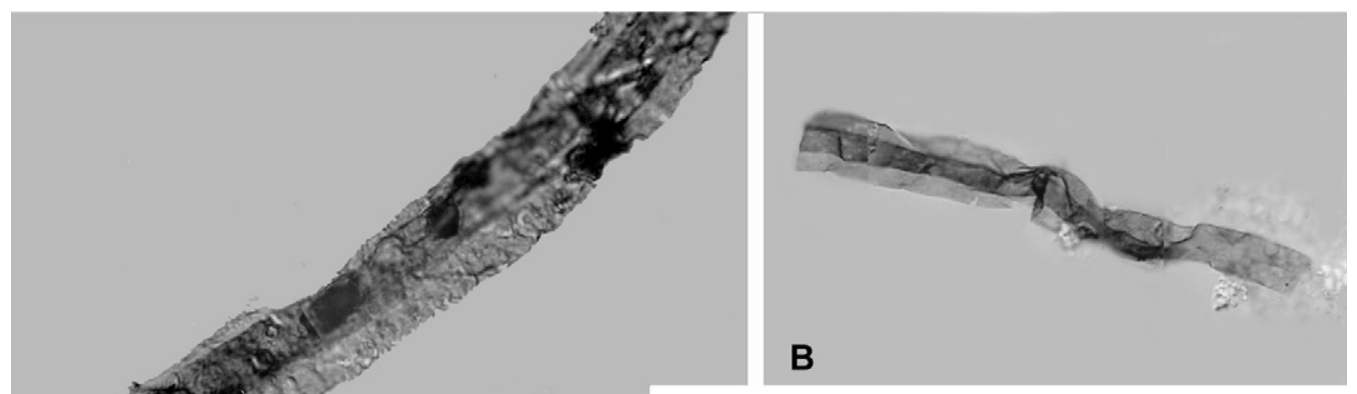

B

A
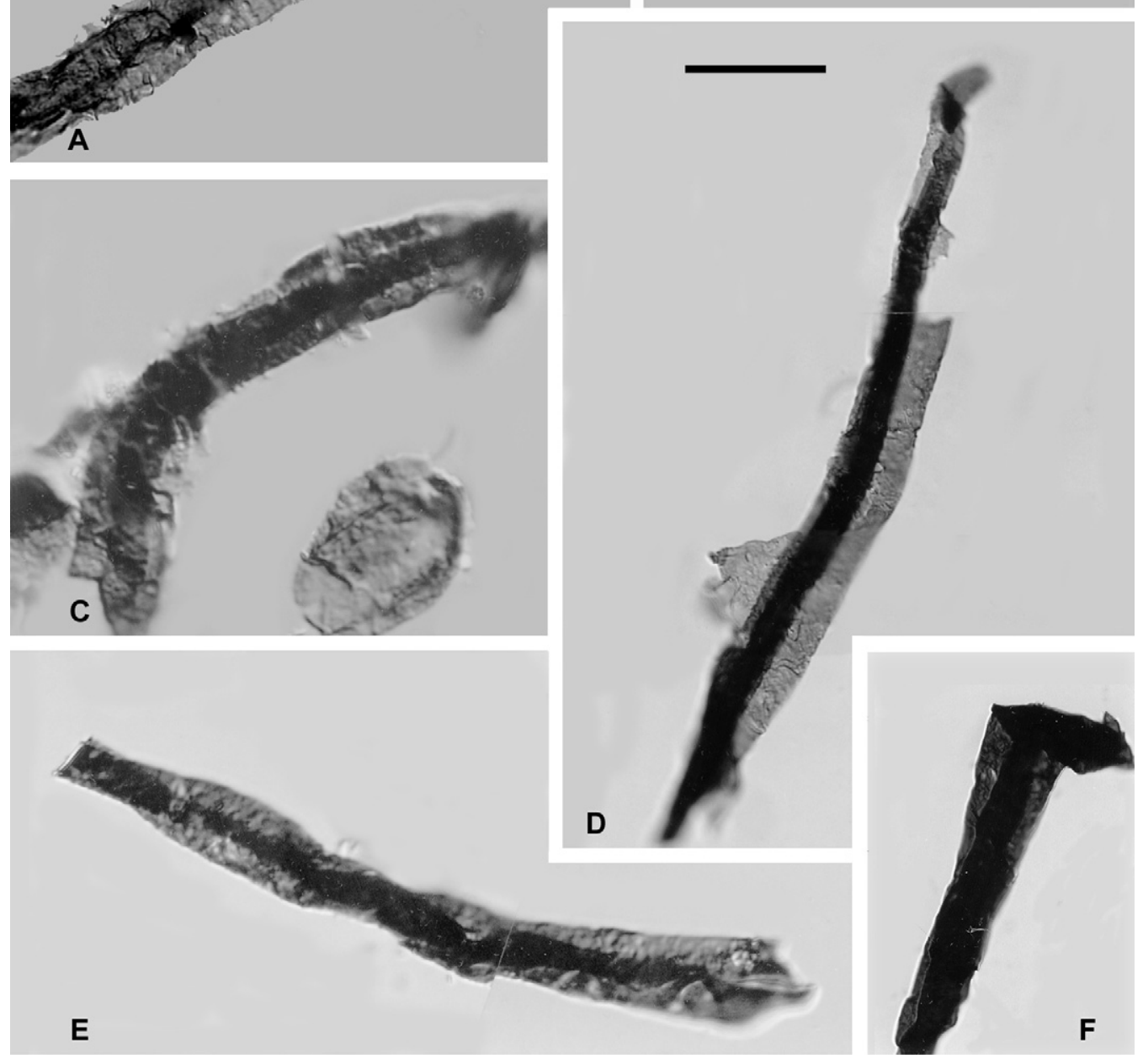

Fig. 6. (A-F) Eoschizothrix composita Seong-Joo and Golubic, 1998. Sample from a depth of $5382.2 \mathrm{~m}$. Filaments showing concentric tube-in-tube structure of the non-branching sheath. (A) Specimen ME-Pl-05/2. X/43. (B) Specimen ME-Pl-05/2. F/51/2. (C) Specimen ME-Pl-05/2. F/46/4. (D) Specimen ME-Pl-05/2.T/38/1. (E) Specimen ME-Pl-05/2.F/473. (F) Specimen ME-Pl-05/2.C/48/4. Scale bar in D equals $35 \mu \mathrm{m}$ for A, C, E and F; $40 \mu \mathrm{m}$ for B; $20 \mu \mathrm{m}$ for D.

The described organic-walled microfossils, and additionally recorded vendotaenids and particulate organic matter, are abundantly preserved in the Ediacaran sediments of the Łopiennik succession. The total organic carbon (TOC) contents measured in these sediments varies between 0.5 and $3.0 \mathrm{mg} / \mathrm{g}$, whereas the values of $\partial^{13} \mathrm{C}(\%$, PDB) for organic carbon are in a range of -34 to $-25 \%$ (Strauss et al., 1997).

\section{Systematic palaeontology}

All microfossils illustrated are in biological microscopic slides, which are housed in the collections of the Museum of Evolution, Palaeontological Section, at Uppsala University (ME-Pl-05). The position of specimens in slides is marked by the Eng- land Finder Coordinates, with the slide label oriented to the left.

Domain Bacteria Woese, Kandler and Wheelis, 1990

Kingdom Eubacteria Woese and Fox, 1977

Phylum Cyanobacteria Stanier, 1977

Class Coccogoneae Thuret, 1875

Order Chroococcales Wettstein, 1924

Family Entophysalidaceae Geitler, 1925

Genus Eoentophysalis Hofmann, 1976, emend. Mendelson and Schopf, 1982

Type species: Eoentophysalis belcherensis Hofmann, 1976; Canada, Hudson Bay, Belcher Islands, unnamed island at Churchill Sound, Belcher Supergroup, ca. 1.9 Ga, upper Kasagalik Formation (Hofmann, 1976, pp. 1070-1072, pl. 6, Fig. 13, holotype). Synonymy:

1976 Eoentophysalis n. gen.-Hofmann, pp. 1069-1070. 

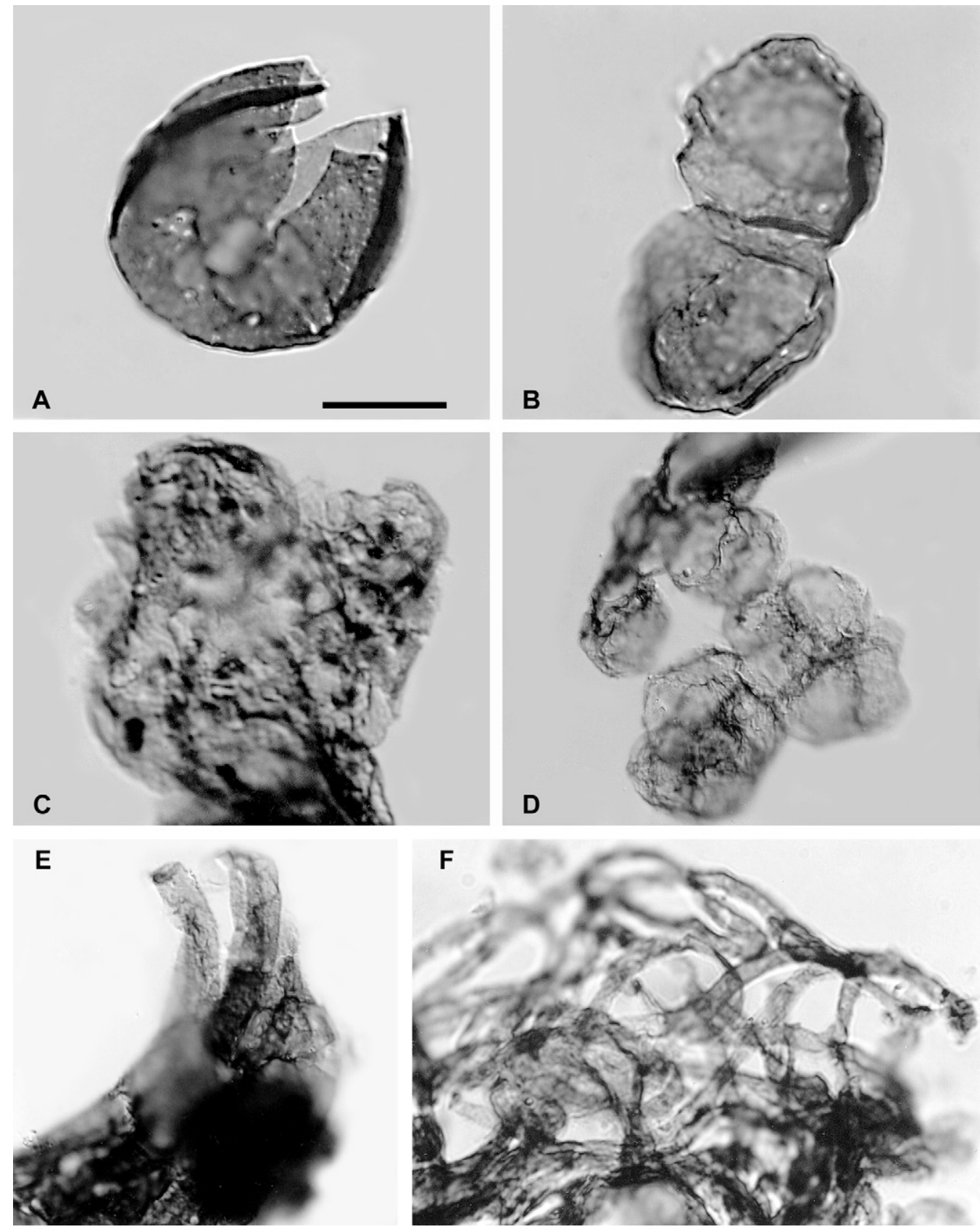

Fig. 7. (A) Leiosphaeridia crassa (Naumova, 1949) Jankauskas, 1989. Specimen ME-Pl-05/1. L/42/4. Spheroidal vesicle with apical rupture (possible excystment structure). (B) Cell division arrested at the anaphase stage of cytokinesis of undetermined spheroidal taxon. Specimen ME-Pl-05/3.Q/32/4. (C and D) Eoentophysalis belcherensis Hofmann, 1976. (C) Specimen ME-PI-05/1.D/48/3. Colony of spheroidal cell-units enveloped by external sheath. (D) Specimen ME-Pl-05/1.M/46/4. Clusters of cell-units preserved in diads and tetrads. (E) Polythrichoides lineatus Hermann, 1974, emend. Hofmann, 1976. Specimen ME-Pl-05/1.G/43/1. Ensheathed multitrichomic filament consisting of several individual cylindrical trichomes. (F) Siphonophycus kestron Schopf, 1968. Specimen ME-PI-05/3.X/48. Cluster of the empty sheaths. (A, C, D and E) Sample from a depth of $5385.6 \mathrm{~m}$; (B and F) Sample from a depth of $5376.7 \mathrm{~m}$. Scale bar in A equals $15 \mu \mathrm{m}$ for A and B; $20 \mu \mathrm{m}$ for C-E; $80 \mu \mathrm{m}$ for F.

1976 Amaliaphycus gen. nov.-Muir, p.153.

1976 Myxomorpha gen. nov.-Muir, p. 155.

Pro parte 1976 Myxococcoides Schopf, 1968-Muir, p. 151 (Myxococcoides kingii sp. nov.=Eoentophysalis belcherensis Hofmann, 1976).

1979 Eoenthophysalis (Sic)-Knoll and Golubic, p. 132. (err. cit. pro Eoentophysalis). 1982 Eoentophysalis Hofmann, 1976, emend.-Mendelson and Schopf, p. 74.

1994 Eoentophysalis Hofmann, 1976, emend. Mendelson and Schopf, 1982-Butterfield et al., 1994, p. 50.

Remarks: The genus Eoentophysalis Hofmann, 1976, emend. Mendelson and Schopf, 1982 embraces a plexus of coccoid colonial microfossils that morphologically and ecologically resemble the modern cyanobacterium Entophysalis Kützing, and in particular E. major Ercegovič̌ and E. granulosa Kützing (Hofmann, 1976; Golubic and Hofmann, 1976; Mendelson and Schopf, 1982; Golubic, 1999a,b). The modern E. major is a mat builder and a major component of mamillate microbial mats in the lowermost intertidal zone and in lagoonal sabhka environments (Golubic, 1999a,b). The microfossils attributed to Eoentophysalis are reported from tidally influenced geological settings often containing stromatolitic beds but also from sediments which are not directly associated with the microbial mat formations (including the present record). Their morphological variability is wide in respect to the shape and size of individual cell-units, and their occurrence in diads, triads, 
tetrads or clusters of numerous cell-units, small geocapsoid colonies and large palmelloid or irregular colonies. This variability depends also on a great variety of preservation and degradation stages of individual cell-units and colonies. The size range of cell-units diagnosed for the genus is $2-20 \mu \mathrm{m}$ (Mendelson and Schopf, 1982), whereas the colonies are from a few tens of micrometres to a few millimetres across. The shape and dimensions of discrete cell-units are strongly affected by post-mortem degradation, distortion and shrinkage and several transitional degradational forms have been recognized depending on the degree of taphonomic alteration. The authors of early studies of these microfossils (Hofmann, 1976; Golubic and Hofmann, 1976; Knoll and Golubic, 1979) reconstructed their divisional stages, degradational variants, life cycles and ontogenetic stages. Golubic and Hofmann (1976) and Golubic (1999a,b) elegantly demonstrated the cell division pattern and degradation of cells in modern counterpart Entophysalis, showing many morphological features in common and revealing similar life cycles of the living Entophysalis major and the fossil Eoentophysalis belcherensis. It is clear from these studies that due to a distortion and fragmentation of colonies in most palaeontological records, the original architecture of the colony is not preserved and that dimensions of cell-units measured on such fossils are also strongly alterted.

\section{Eoentophysalis belcherensis Hofmann, 1976 (Fig. 7C-D)}

Synonymy: For additional synonymy see Sergeev (2006, p. 196) 1976 Eoentophysalis belcherensis n.sp.-Hofmann, pp. 1070-1072, pl. 4, Figs. 1-5; pl. 5, Figs. 3-6; pl. 6, Figs. 1-14.

1976 Eoentophysalis belcherensis-Golubic and Hofmann, pl. 1, Fig. 7; pl. 2, Fig. 4. 2006 Eoentophysalis dismallakesensis Horodyski and Donaldson, 1980-Sergeev, pp. 198-199, pl. XIII, Figs. 2-6, 8, 9; pl. XXXI, Figs. 1-6; pl. XXXII, Figs. 5, 6, 8; pl. XLII, Figs. 10-11, pl. XLVI, Figs. 11-12.

2006 Eoentophysalis belcherensis Hofmann, 1976-Sergeev, pp. 196-197, pl. VIII, Figs. 3, 6, 7, 10; pl. XLI, Figs. 13-15.

Material: More than 20 specimens in various states of preservation, preserved as solitary cell-units and clusters; cell-units are empty inside and often contain shrunken organic matter remains. The cells are often distorted and flattened; clusters are probable fragments of larger colonies and/or microbial mats.

Description: Cell-units spheroidal to subpolyhedral, $12-16 \mu \mathrm{m}$ in cross-section diameter, occurring in diads, triads or planar tetrads, and as irregular, multilayered clusters of numerous individual cell-units. The discrete cell-units are empty inside or contain the internal structures in the form of circular to oval opaque inclusions in the central position within the cell-unit. The external envelopes enclosing diads or colonies are occasionally preserved.

Dimensions: The cross-section diameter of cell-units is $12-16 \mu \mathrm{m}(N=16)$.

Present record: Łopiennik IG-1 borehole at a depth of 5382.2 and $5385.6 \mathrm{~m}$, Włodawa Formation, upper Ediacaran.

Occurrence and stratigraphic range: The occurrence is worldwide and in a wide stratigraphic range; the earliest in Canada, Hudson Bay, Belcher Islands, Belcher Supergroup, ca. 1.9 Ga, Kasagalik and McLeary formations (Hofmann, 1976), throughout the Lower Proterozoic to the Vendian (Sergeev, 2006). The species is thus long-lived, from ca. $1.9 \mathrm{Ga}$ to $600 \mathrm{Ma}$ (previous records), and extended to $c a .545 \mathrm{Ma}$ by the present record (Fig. 3).

Class Hormogoneae Thuret, 1875

Order Oscillatoriales Copeland, 1936

Family Oscillatoriaceae Kirchner, 1898

Genus Eoschizothrix Seong-Joo and Golubic, 1998

Type species: Eoschizothrix composita Seong-Joo and Golubic, 1998; North China, Hebei Province, Pangjapu Iron Mine area, Gaoyuzhuang Formation, Mesoproterozoic, ca. 1.4-1.5 Ga (Seong-Joo and Golubic, 1998, pp. 181-182, Fig. 2B, holotype). Remarks: Seong-Joo and Golubic $(1998,1999)$ and Seong-Joo et al. (1999) described the morphology of Eoschizothrix in detail, its taphonomy, comparison with other multi-trichomous fossil taxa, and palaeoenvironmental reconstruction within the microbial mat layers of the stratiform stromatolites. They documented that this is a fossil counterpart of the sheathed, multi-trichomous, modern oscillatoriacean cyanobacterium Schizothrix and it has occurred in the same environments, as inferred from the sedimentological record. The modern genus is a dominan microorganism in mat communities, dynamically acting (gliding and vertically uprising against the sediment influx) during the process of mat growth and building the frame of mats (Golubic, 1999a,b). Schizothrix is a major component of pinnacled mats and the dominant taxon in the lower portions of the convoluted and folded mats characteristic for sabkha (salt flats) and intertidal lagoonal coast environments.

\section{Eoschizothrix composita Seong-Joo and Golubic, 1998 (Fig. 6A-F)}

Synonymy:

1991 Tubular cyanobacterial sheaths-Moczydłowska, pl. 14 J.
1998 Eoschizothrix composita n. sp.-Seong-Joo and Golubic, pp. 181-182, Figs. 2, 3, $5,6,10$.

1999 Eoschizothrix composita Seong-Joo and Golubic, 1998-Seong-Joo, Golubic and Zhang Yun, pp. 252-253, pl. 4, Figs. 1-3; pl. 5, Figs. 3-4.

2006 Eoschizothrix composita Seong-Joo and Golubic, 1998-Sergeev, p. 209, pl. XXV, Figs. 2, 4 and 5.

Material: Sixteen specimens in a fairly good state of preservation with single internal tubules preserved within the outer sheath and no cell-units in the trichome.

Description: Filaments consisting of two concentric, cylindrical, unbranched sheaths enclosed within each other and of almost constant cross-section diameter along their length. The wall surface of both sheaths is smooth and their endings are open. Dimensions: $N=10$. The cross-section diameter of inner sheath is $3-8 \mu \mathrm{m}$ and the outer sheath is $10-18 \mu \mathrm{m}$. The length of preserved fragments of filaments is over 100-150 $\mu \mathrm{m}$.

Remarks: The sheaths are composed of resilient and flexible organic matter and are not encrusted by any mineral compounds as displayed by softly bending and deformed specimens (Fig. 6B and F). The surface of outer sheath may appear to be wrinkled or pseudo-plicated (Fig. 6A) but this is a taphonomic feature resulting from the post-mortem and/or diagenetic degradation of the originally psilate wall seen in well-preserved specimens (Fig. 6B). The inner sheath may be moved within the outer sheath from a central position (Fig. 6A) or destroyed entirely (Fig. 6B, right side) but this is also considered to be due to the taphonomic changes.

The inner sheaths are darker, and this is not only the optical effect of being superimposed with the outer sheaths but their wall was also probably thicker than that of the outer sheaths. The rectangular (in outline) organic inclusions inside the inner sheath (Fig. 6A, centre) may be remains of cells in trichome although the black, isometric and euhedral cubic structures that are randomly scattered on the outer sheath and embedded within its wall are interpreted as imprints after pyrite crystal growth (Fig. 6A, upper portion).

Present record: Łopiennik IG-1 borehole at a depth of 5376.7, 5382.2 and $5385.6 \mathrm{~m}$, Włodawa Formation, upper Ediacaran.

Occurrence and stratigraphic range: North China, Hebei Province, Pangjapu Iron Mine area, Gaoyuzhuang Formation, Mesoproterozoic, ca. 1.4-1.5 Ga (Seong-Joo and Golubic, 1998, 1999; Seong-Joo, Golubic and Zhang, 1999). Poland, Lublin Slope of the East European Platform, Terebin IG-5 borehole at 3672.0 m, Lublin Formation, Ediacaran (Moczydłowska, 1991). Yakutia, Siberian Platform, Uchur-Maya area, Aldan River and Belaya River sections, Yudoma Group, Vendian (=Ediacaran) (Sergeev, 2006).

Genus Palaeolyngbya Schopf, 1968, emend. Butterfield et al., 1994

Type species: Palaeolyngbya barghoorniana Schopf, 1968; Australia, Northern Territory, Amadeus Basin, Ross River area near Alice Springs, Bitter Springs Formation late Precambrian, ca. $1 \mathrm{Ga}$ (Schopf, 1968, pp. 665-666; Schopf, 1992, p. 1093, pl. 32C, holotype re-photographed); the age of the formation was re-evaluated as Neoproterozoic, ca. $850 \mathrm{Ma}$ (Mendelson and Schopf, 1992).

Synonymy:

1968 Palaeolyngbya Schopf, n. gen.-Schopf, p. 665

1974 Paleolyngbya (Sic) Schopf, 1968-Hermann, p. 8

1994 Palaeolyngbya Schopf, 1968, emend.-Butterfield, Knoll and Swett, pp. 60-61. See Butterfield et al. (1994) for detailed synonymy of the genus and the emended diagnosis.

Palaeolyngbya catenata Hermann, 1974 (Figs. 4A-F, H and 5A-C) Synonymy: See detailed synonymy by Butterfield et al. (1994) and Sergeev (2006). Additionally:

1974 Paleolyngbya (Sic) catenata sp. n.-Hermann, pp. 8-9, pl. VI, Fig. 5.

1992 Palaeolyngbya catenata Hermann (=German) 1974-Mendelson and Schopf, p. 915.

1992 Palaeolyngbya catenata Hermann (=German) 1976 (Sic)-Schopf, p. 1136.

1994 Palaeolyngbya catenata Hermann, 1974-Butterfield et al., 1994, p. 61, Fig. 25F-G.

2006 Palaeolyngbya catenata Hermann, 1974-Sergeev, p. 207, pl. XXII, Figs. 4-6; pl. XXVII, Figs. 1-3.

Material: Numerous (over 30) filaments with cells in excellent and good state of preservation.

Description: Trichomes containing uniseriate and unbranched chains of rectangular cells within the surrounding simple, tubular, smooth sheath.

Dimensions: The width of sheaths is $16-21 \mu \mathrm{m}$; the cells inside are 7-15 $\mu \mathrm{m}$ in width and $2-5 \mu \mathrm{m}$ in length $(N=20)$. The fragments of trichomes are $120-150 \mu \mathrm{m}$ in total length.

Remarks: Hermann (1974) provided the dimensions of the cells inside the trichome as $11-15 \mu \mathrm{m}$ in width and $4-5 \mu \mathrm{m}$ in length in her diagnosis of the species, whereas the width of sheaths in the original description is given as $10-25 \mu \mathrm{m}$. The microfossils described here are within this size class. The size range of sheaths included in the diagnosis of P. catenata by Butterfield et al. (1994), although there is no for- 
mal emendation of the species, is $10-30 \mu \mathrm{m}$ in diameter, yet the sheath width in the material described there is $8-16 \mu \mathrm{m}$ and thus below the lower range diagnosed. In a recent monographic work, Sergeev (2006) followed the taxonomic classification by Butterfield et al. (1994) but extended the size range of filament diameter to $19.0-40.0 \mu \mathrm{m}$, width of cells $14.0-26.0 \mu \mathrm{m}$, length of cells $2.0-6.0 \mu \mathrm{m}$.

The cells are rectangular, attached to each other or aligned with some distance due to the progressing disintegration of trichomes. Occasionally, the cells are preserved in pairs closely attached and separated from the other pairs (Fig. 4D). The cell width (crosssection diameter) is much smaller than the width of the enclosing sheath and this is an apparent morphologic feature as inferred by comparison to the reduction of the length of the cells due to a taphonomic shrinkage affecting the entire cell. The cells are not randomly deformed but rectangular and differ in length or width only. The sheath was originally tubular and nonseptate but it seems, during ontogeny and passing into more mature stages, that it became segmented. This is particularly seen in more degraded specimens. The segmentation follows the pattern of cell distribution within the sheath (one cell in one segment) but the septa are not developed. The sheath breaks along the segment limits into regular transversal bands but there are neither incisions nor deformation at these limits.

Present record: Łopiennik IG-1 borehole at a depth of 5376.7, 5382.2 and $5385.6 \mathrm{~m}$, Włodawa Formation, upper Ediacaran.

Occurrence and stratigraphic range: Yakutia, East Siberian Platform, Krasnoyarsk District, Turukhansk region, Miroedikha River section, Miroedikha Formation, Upper Riphean (Hermann, 1974), estimated to ca. 850 Ma (Mendelson and Schopf, 1992); Uchuro-Maya region, Svetlin and Satkin formations, Middle Riphean to Vendian (Sergeev, 2006). South Urals, Burzyan Formation, Lower Riphean, ca. 1650-1350 Ma (Sergeev, 2006). Arctic Canada, Dismal Lakes Group, Middle Proterozoic (Horodyski and Donaldson, 1980). China, Hebei Province, Gaoyuzhuang Formation, Riphean (Y. Zhang, 1981); Hubei Province, late Precambrian (Z. Zhang, 1981). Spitsbergen, Geerabukta locality, Svanbergfjellet Formation, Algal Dolomite Member, and other localities, Svanbergfjellet Formation, Lower Dolomite Member; Neoproterozoic, ca. 700-750 Ma (Butterfield et al., 1994).

The total range is within the time interval of $\mathrm{ca}$. $1650 \mathrm{Ma}$ (Sergeev, 2006) to ca. $545 \mathrm{Ma}$ (present record).

Genus Polythrichoides Hermann, 1974, emend. Hofmann, 1976

Type species: Polythrichoides lineatus Hermann, 1974, emend. Hofmann, 1976: Yakutia, East Siberian Platform, Krasnoyarsk District, Turukhansk region, Miroedikha River section, Miroedikha Formation, Upper Riphean (Hermann, 1974; Hermann in Timofeev and Hermann, 1976). The absolute age of the Miroedikha Formation is estimated to $\mathrm{ca} .850 \mathrm{Ma}$ in Mendelson and Schopf (1992, p. 873). By original designation. Synonymy:

1974 Polythrichoides gen. n.-Hermann, pp. 7-8

1976 Polythrichoides Hermann, 1974, emend. 1976-Hermann in Timofeev and Hermann, p. 37.

1982 Plythrichoides (Sic) Hermann, 1974, emend. Hermann 1976-Jankauskas, p. 110 (Misspelled generic name).

1982 Polythrichoides Hermann, 1974, emend. Hofmann, 1976-Jankauskas, p. 113.

1989 Polytrichoides (Sic) Hermann, 1974, emend. Hofmann, 1976-Jankauskas et al., p. 119 (Misspelled generic name).

1990 Polytrichoides (Sic) Hermann, 1974 emended 1976-Hermann, p. 28 (Misspelled generic name)

1992 Polytrichoides (Sic) Hermann emend. Hofmann, 1976-Zang and Walter, p. 315 (Misspelled generic name)

1994 Polythrichoides Germann, 1974, emend. Timofeev et al., 1976-Hofmann and Jackson, p. 12.

2006 Polytrichoides (Hermann) Hofmann, 1976-Shukla et al., p. 62

Polythrichoides lineatus Hermann, 1974, emend. Hofmann, 1976

(Fig. 7E)

Synonymy:

1974 Polythrichoides lineatus gen. et sp. n.-Hermann, pp. 7-8, pl. VI, Fig. 3 (holotype), 4.

1976 Polythrichoides lineatus Hermann, 1974-Timofeev and Hermann, p. 37, pl. XIV, Fig. 7.

1982 Plythrichoides (Sic) lineatus Hermann, 1974, emend. Hofmann, 1976-Jankauskas, p. 110 (Misspelled generic name).

1982 Polythrichoides lineatus Hermann, 1974, emend. Hofmann, 1976-Jankauskas, p. 113, pl. XLV, Fig. 6; pl. XLVIII, Fig. 16

1985 Polythrichoides lineatus Hermann-Xing et al., p. 64, pl. 12, Fig. 10

1985 Polythrichoides lineatus Herm.-Jankauskas in Sokolov and Ivanovskij, p. 146, pl. 61, Fig. 3.

1989 Polytrichoides (Sic) lineatus Hermann, 1974, emend. 1976-Jankauskas et al., pp. 119-120, pl. XXX, Figs. 5-7 (Misspelled generic name).

1990 Polytrichoides (Sic) lineatus Hermann, 1974 emend. 1976-Hermann, p. 28, pl. IX, Figs. 8 and 9 (Erroneously cited as 8, 8a; misspelled generic name).

1990 Polythrichoides lineatus Herm.-Jankauskas in Sokolov and Ivanowski, p. 172, pl. 61, Fig. 3.

1991 Polythrichoides lineatus Hofmann, 1976-Yin, p. 263, pl. 4, Fig. 11.

1991 Polytrichoides (Sic) lineatus Germann, 1974 emend.-Knoll, Swett and Mark, p. 563, Figs. 4.3, 4.5 .

1992 Polythrichoides lineatus Hermann (=German) 1974-Schopf, p. 1088, pl. 27 A , $\mathrm{A}_{2}$ (paratype re-photographed).

1992 Polytrichoides (Sic) lineatus Hermann emend. Hofmann, 1976-Zang and Walter, pp. 315-316, pl. XVII A-E (Misspelled generic name).

1994 Polythrichoides lineatus Germann, 1974 emend. Knoll et al., 1991-Hofmann and Jackson, pp. 12-13, Figs. 11.13-11.17.

2006 Polythrichoides lineatus (Hermann) Hermann, in Timofeev et al., 1976-Shukla et al., p. 62.

2006 Polythrichoides lineatus (Hermann) Knoll et al., 1976-Shukla et al., pp. 62-64, pl. II, Figs. 2 and 3.

Material: Seven relatively well preserved specimens formed by bundles consisting of a few individual tubular trichomes.

Description: Ensheathed multitrichomic filaments comprising bundles of 5-7 tubular, individual internal sheaths (originally trichomes), parallel and tightly arranged within a common outer sheath. The surface of the outer enveloping sheath and enclosed tubular internal sheaths (emptied trichomes) is psilate. The internal sheaths are nonseptate, unbranched and of an equal cross-section diameter; they become separated from each other and widely spread at the (broken) end of the enclosing sheath. No cells are preserved in the internal tubular sheaths.

Dimensions: The cross-section diameter of individual internal sheaths (original trichomes) is $6-8 \mu \mathrm{m}$, and outer sheath is $35-40 \mu \mathrm{m}(N=4)$.

Remarks: The species was not formally emended by Hermann in Timofeev and Hermann (1976), but the genus Polythrichoides of which it is the type species; however, by default, it was treated as such by Jankauskas (1982) and followed by other authors.

Hofmann and Jackson (1994, p. 12) accepted that the species P. lineatus was emended by Knoll et al. (1991), although the latter authors did not actually provide the emendation to the species diagnosis but only a general discussion. Knoll et al. (1991, p. 563) referred it to as "Genus Polytrichoides (Sic) lineatus German, 1974, emend". The original emendation by Hermann (1976 in Timofeev and Hermann, 1976) is retained here.

The cross-section diameter of individual internal tubular sheaths in the present collection exceeds slightly the dimensions of the specimens from the type material from the Siberian Platform, which is 3.0-5.0 $\mu \mathrm{m}$ (Hermann, 1974; Timofeev and Hermann, 1976), or 2.5-6.0 $\mu \mathrm{m}$ from other occurrences (Jankauskas et al., 1989). The number of trichomes in ensheathed filament is diagnosed to be five but it is observed to be greater.

Present record: Łopiennik IG-1 borehole at a depth of $5385.6 \mathrm{~m}$, Włodawa Formation, upper Ediacaran.

Occurrence and stratigraphic range: Yakutia, East Siberian Platform, Krasnoyarsk District, Turukhansk region, Miroedikha River, Miroedikha Formation, Upper Riphean (Hermann, 1974; Timofeev and Hermann, 1976), ca. $850 \mathrm{Ma}$ (Mendelson and Schopf, 1992); Uchur-Maya region, Khabarovsk District, Maya River, Lakhanda Formation, Upper Riphean (Jankauskas et al., 1989), ca. $950 \mathrm{Ma}$ (Mendelson and Schopf, 1992). South Urals, Zilmerdak Formation, ca. 1000 Ma; Podinzer Formation (=Sim Formation), ca. $925 \mathrm{Ma}$; Zilim River, Uk Formation (=Kudash Formation), ca. 675 Ma; Zigan River, Zigan Formation; Bashkiria, Kabakovo 62 borehole at a depth of 3636.0-3678.0 m (Jankauskas, 1982; Mendelson and Schopf, 1992), and Sergeevsk800 borehole, 2942.5-2946.4 m, Baikibashev Formation, Vendian (Jankauskas, 1985 , 1990). Russia, Zimny Coast of the White Sea, Archangelsk area, Zimnie Gory beds, Vendian, Redkino stage (Ragozina and Sivertseva, 1990). Russia, Smolensk region, and Belorus and Moldova, East European Platform, Redkino Formation, Lower Vendian (Aseeva, 1983). Arctic Canada, Baffin Island, Bylot Supergroup (1270-750 Ma), Eqalulik Group, Arctic Bay Formation and AB Formation (1270 Ma), Nunatsiaq Group, Elwin Formation (750 Ma) (Hofmann and Jackson, 1994). NE Spitsbergen, Draken Conglomerate Formation, Neoproterozoic (800-700 Ma; Knoll et al., 1991). China, Jiao-Liao-Xu-Huai Province, Qiaotou and Changlingzi formations, Lower Sinian (Xing et al., 1985); western Shandong, Tongjiazhuang Formation, Upper Proterozoic ca. 
800-700 Ma (Yin, 1991); northern Anhui, Huainan Group, Liulaobei Formation, Upper Sinian (Zang and Walter, 1992).

The total range of the species is from Mesoproterozoic to Ediacaran, ca. 1270-545 Ma (Hofmann and Jackson, 1994; and present record).

Genus Rugosoopsis Timofeev and Hermann, 1979, emend. Butterfield et al., 1994 Type species: Rugosoopsis tenuis Timofeev and Hermann, 1979; Yakutia, south-east Siberian Platform, Uchur-Maya region, Khabarovsk District, Maya River section, Lakhanda Formation, Upper Precambrian, Upper Riphean (ca. $930 \mathrm{Ma}$; Timofeev and Hermann, 1979; Hermann, 1990). The absolute age of the Lakhanda Formation is estimated to ca. 950 Ma by Mendelson and Schopf (1992, p. 907) and the holotype is re-photographed (ibidem, p. 1074, pl. 13C). By original designation. Synonymy:

1979 Rugosoopsis Timofeev et Hermann. gen.nov.-Timofeev and Hermann, p. 139. 1980 Plicatidium Jankauskas, gen.nov.-Jankauskas, p. 109.

Non 1984 Karamia Kolosov, gen.nov.-Kolosov, pp. 39-40.

1989 Tubulosa=Rugosoopsis corrugata (Aseejeva, 1982); T. = Rugosoopsis jampolica (Aseejeva, 1982)-Jankauskas et al., pp. 139-140.

1990 Rugosoopsis-Hermann, p. 20, pl. V, Fig. 5.

1992 Rugosoopsis Timofeev and Hermann [German] 1979-Schopf, p. 907.

Pro parte 1994 Rugosoopsis Timofeev and Hermann, 1979, emend.-Butterfield et al., pp. 61-62. (Non Karamia Kolosov, 1984, belonging by default into the emended Rugosoopsis by including the type species K. segmentata into synonymy of Rugosoopsis tenuis).

Rugosoopsis tenuis Timofeev and Hermann, 1979, emend. Butterfield et al., 1994 (Fig. 9A)

Synonymy:

1979 Rugosoopsis tenuis Timofeev et Hermann. gen. et sp. nov.-Timofeev and Hermann, p. 139, pl. XXIX, Figs. 5 and 7.

1980 Siphonophycus costatus Jankauskas, sp. nov.-Jankauskas, pp. 108-109, pl. XII, Figs. 1 and 10.

1982 Tubulosa corrugata Aseejeva gen et sp. nov.-Aseeva, p. 13, pl. 2, Figs. 10 and 11 1982 Siphonophycus costatus Jankauskas, 1980-Jankauskas, p. 119, pl. XXXVI, Fig. 12; pl. XXXIX, Figs. 1, 3, 8; pl. XLVII, Fig. 1, non 2.

1987 Siphonophycus costatus Jankuskas, $1980-Y$ in, p. 480, pl. 11, Figs. 1, 3, 4, non 11 ; non pl., 10, Figs. 1, 6, 11.

1989 Rugosoopsis tenuis Timofeev et Hermann, 1979-Jankauskas et al., pp. 139-140, pl. XXIX, Fig. 3

1991 Tubular cyanobacterial sheaths-Moczydłowska, pl. 15A-B.

1992 Rugosoopsis tenuis Timofeev \& Hermann [=German] 1979-Schopf, p. 1074, pl. 13C (holotype re-photographed).

Pro parte 1994 Rugosoopsis tenuis Timofeev and Hermann, 1979, emend.-Butterfield et al., 1994, p. 62, Figs. 25A-D, 27B. (Species of Karamia excluded from its synonymy). Material: Four specimens poorly preserved.

Description: Bi-layered, filamentous, flattened, tubular sheaths consisting of inner smooth sheath and the outer sheath with transverse tight plications.

Dimensions: The width of sheath is $18-20 \mu \mathrm{m}$, length is over $140 \mu \mathrm{m}(N=4)$

Remarks: Butterfield et al. (1994) synonymized the type species and all other species of the genus Karamia Kolosov, 1984 with Rugosoopsis tenuis Timofeev and Hermann, 1979 emend., which is the type species of the emended by them genus Rugosoopsis. Accepting this, the genus Karamia would become by default a junior synonym of the emended Rugosoopsis. The diagnostic feature of Karamia is the presence of septa and clearly constricted filament wall at the contact with septa (Kolosov, 1984), which distinguishes this genus from the bi-layered filaments of Rugosoopsis, having plications or transverse fabric on the outer sheath wall. The genus Rugosoopsis emended by Butterfield et al. (1994) and its type species $R$. tenuis are accepted here pro parte because of the exclusion of the species of Karamia from their synonymy.

The transfer of two species of the genus Tubulosa Aseeva, 1982, T. corrugata (type species) and T. jampolica, to Rugosoopsis by Jankauskas et al. (1989, pp. 139-140), and then establishing the synonymy between $R$. tenuis and $T_{\text {. }}=R$. corrugata (as a junior synonym) by Butterfield et al. (1994), render the genus Tubulosa to become a junior synonym of Rugosoopsis. The species $R$. jampolica is considered here also a junior synonym of $R$. tenuis.

Present record: Łopiennik IG-1 borehole at a depth of $5385.6 \mathrm{~m}$, Włodawa Formation, upper Ediacaran.

Occurrence and stratigraphic range: Yakutia, south-east Siberian Platform, UchurMaya region, Khabarovsk District, Maya River section, Lakhanda Formation, Upper Precambrian, Upper Riphean, ca. 930 Ma (Timofeev and Hermann, 1979; Hermann, 1990), the age of the Lakhanda Formation is estimated to ca. 950 Ma by Schopf (1992, p. 907); Uchur-Maya region, Neryuensk Formation, Upper Riphean (Jankauskas et al., 1989); South Urals and Bashkiria, Limeza River section, Bederyshinsk Formation,
Zilim River section, Uksk Formation, Chernaya River section, Zilimerdak Formation, the Kabakovo 62 borehole at depth of 3526.0-3528.0 $\mathrm{m}$ and 3636.0-3639.0 m, Upper Riphean (Jankauskas, 1980, 1982); China, Jilin Province, Hunjiang District Qinggou Formation, Upper Riphean (Yin, 1987); Spitsbergen, Geerabukta locality, Svanbergfjellet Formation, Lower Dolomite Member and Algal Dolomite Member, Neoproterozoic, ca. 700-750 Ma (Butterfield et al., 1994). Poland, Lublin Slope of the EEP, Łopiennik IG-1 borehole at a depth of $5198.6 \mathrm{~m}$, Mazowsze Formation, lowermost Cambrian, Asteridium-Comasphaeridium Zone (Moczydłowska, 1991).

In summary, the biochronological range of the species is Neoproterozoic to early Cambrian, at ca. 950-540 Ma (Schopf, 1992; Moczydłowska, 1991; present record).

Genus Siphonophycus Schopf, 1968, emend. Knoll et al., 1991.

Type species: Siphonophycus kestron Schopf, 1968; Australia, Northern Territory, Amadeus Basin, Ross River area near Alice Springs, Bitter Springs Formation (ca. $1 \mathrm{Ga}$; Schopf, 1968). The absolute age was re-evaluated to $c a .850$ Ma by Mendelson and Schopf (1992). By original designation.

Synonymy:

1968 Siphonophycus Schopf, n. gen.-Schopf, p. 671

1968 Tenuofilum Schopf, n. gen.-Schopf, p. 679.

1968 Eomycetopsis Schopf, n. gen.-Schopf, pp. 684-685.

1974 Leiothrichoides gen. n.-Hermann, pp. 8-9, pl. VI, Figs. 1 and 2.

1979 Leiothrichoides Hermann, 1974 emend. 1978 (Sic)-Timofeev and Hermann, p. 138. (Sic; should be 1979).

1979 Eomycetopsis Schopf em. (Schopf, 1968, p. 684)-Knoll and Golubic, p. 149.

1982 Leiothrichoides Hofmann, 1976 (Sic)-Jankauskas, p. 110. (Sic; should be 1974). 1982 Eomycetopsis Schopf, 1968-Jankauskas, p. 111.

1982 Leiothrichoides Hermann, 1974 emend. Hermann, 1979-Jankauskas, p. 112.

Non 1982 Siphonophycus Schopf, 1968-Jankauskas, p. 119 (Siphonophycus costatus Jankauskas, $1980=$ Rugosoopsis tenuis).

Pro parte 1989 Siphonophycus Schopf, 1968-Jankauskas et al., pp. 121-122. [Non Siphonophycus attenuatum A. Weiss, sp. nov., pl. XXV, Figs. 6 and 7 (=Tortunema; non Cephalonyx in Butterfield et al., 1994, p. 62)].

1989 Eomycetopsis Schopf, 1968, emend. Knoll et Golubic, 1979-Jankauskaset al. p. 106 (E. lata Golovenoc et Belova, 1985 = Siphonophycus kestron; E. robusta Schopf, 1968, emend. Knoll et Golubic, 1979= Siphonophycus robustum).

? 1991 Siphonophycus Schopf, 1968, emend.-Knoll, Swett and Mark, p. 563.

1992 Siphonophycus Schopf, 1968-Mankiewicz, p. 985.

1994 Siphonophycus Schopf, 1968, emend. Knoll, Swett \& Mark, 1991-Butterfield et al., pp. 62-64.

Remarks: Morphologically simple, tubular, smooth, nonseptate and unbranched sheaths are described under the form-genus Siphonophycus Schopf, 1989 emend. Knoll, Swett and Mark, 1991, which includes several other genera with equally nondiagnostic features as synonyms.

The differences in the shape of sheath terminations, being rounded, blunt or capitate, were used to determine the genera, but this is mostly an artificial feature reflecting state of preservation observed on microfossils, as most specimens are incomplete with broken or atrophied distal portions, and/or have a little systematic significance. Lamellated or unlamellated sheath wall seems also to be a preservation feature, whereas the wall thickness is difficult to measure precisely and may be rather related proportionally to the dimensions of the sheath. The high variability in the cross-section diameter of the sheaths, alternatively called sheath diameter or width, was applied to recognise the species. Several different size classes have been proposed to define the species but these classes have been arbitrarily chosen and often are overlapping in their ranges depending on the abundance of the specimens measured. The size frequency distribution does not necessary reflect the natural populations, as the collections for such studies were too small for reliable statistical matrices or deriving from bulk samples, with a few exceptions of microbial mat samples studied in thin sections (e.g. Knoll et al., 1991).

\section{Siphonophycus kestron Schopf, 1968 (Figs. 4G and 5F)}

\section{Synonymy:}

See detailed synonymy by Butterfield et al. (1994).

1968 Siphonophycus kestron Schopf, n. sp.-Schopf, p. 671, pl. 80, Figs. 1-3.

1989 Eomycetopsis lata Golovenoc et Belova, 1985-Jankauskas et al., pp. 106-107, pl. XX, Fig. 4.

1991 Siphonophycus kestron Schopf, 1968-Knoll, Swett and Mark, Fig. 4:1. 1992 Siphonophycus kestron Schopf, 1968-Schopf, p. 1092, pl. 31J (paratype rephotographed).

1994 Siphonophycus kestron Schopf, 1968-Butterfield et al., p. 67, Fig. 21D. 1997 Siphonophycus kestron Schopf, 1968-Cotter, p. 263, Fig. 8H.

2006 Siphonophycus kestron Schopf, comb. Butterfield, 1994-Sergeev, pp. 214-215, pl. XXII, Figs. 1 and 2; pl. XXVIII, Fig. 3; pl. XXXVI, Fig. 3; pl. XLIV, Fig. 11; pl. XLV, Figs. 3 and 6 .

Material: Over hundred solitary and clustered filaments in various states of preservation.

Description: Tubular, nonseptate, unbranched, thin-walled sheaths with psilate surface and equal cross-section diameter along the length of sheath. The individual 
filaments are straight, sinuous or softly looped, mostly flattened and abruptly terminated (broken apart).

Dimensions: $N=45$. The cross-section diameter of sheaths is 9-12 $\mu \mathrm{m}$, length of incomplete specimens varies between 140 and $330 \mu \mathrm{m}$.

Remarks: The definition of form-species of the genus Siphonophycus emended by Butterfield et al. (1994) and based on the size classes chosen by them justify the transfer of Eomycetopsis lata Golovenoc and Belova, 1985 as a junior synonym to $S$. kestron.

Present record: Łopiennik IG-1 borehole at a depth of 5376.7, 5382.2 and $5385.6 \mathrm{~m}$, Włodawa Formation, upper Ediacaran.

Occurrence and stratigraphic range: The species is very common worldwide within the stratigraphic range of Middle Proterozoic to terminal Ediacaran, $c a .1650-545 \mathrm{Ma}$ (Mendelson and Schopf, 1992; Sergeev, 2006; and present record). Some of the occurrences in the isotopically dated successions are: ca. $1425 \mathrm{Ma}$ Changcheng Group, Gaoyuzhuang Formation in China; ca. 900 Ma Deoban Limestone in India; ca. $850 \mathrm{Ma}$ Bitter Springs Formation in the Amadeus Basin, Australia; ca. $750 \mathrm{Ma}$ Ryssö Formation, Nordaustlandet, Svalbard; ca. 550 Ma Adeyton Group, Random Formation, Canada, Newfoundland (Mendelson and Schopf, 1992); ca. 700-750 Ma Svanbergfjellet Formation, Spitsbergen (Butterfield et al., 1994).

Additionally, the Browne Formation, Officer Basin, Western Australia, early Neoproterozoic (Cotter, 1997). NE Siberian Platform, Yakutia, Svetlin Formation, Middle Riphean; Aldan River section, Yudoma Formation, Vendian; South Kazakhstan, Maly Karatau, Chikchan Formation, Vendian; South Urals, Satkin, Avzyan and Minyar formations, Lower to Upper Riphean, respectively (Sergeev, 2006).

Siphonophycus typicum (Hermann, 1974) Butterfield, 1994 (Fig. 5E)

Synonymy: See for extended synonymy Butterfield et al. (1994). Additionally: 1974 Leithrichoides typicus gen. et sp. n.-Hermann, p. 7, pl. VJ, Figs. 1 and 2.

1992 Leithrichoides typicus (Hermann, 1974) emend. Hermann (=German) 1979-Schopf, p. 1088, pl. 27 B B $_{4}$ (paratype re-photographed).

1994 Siphonophycus typicum (Hermann, 1974) Butterfield, n. comb.-Butterfield et al., pp. 66-67, Figs. 23B-D, 26B, H, J

2006 Siphonophycus typicum (Hermann) comb. Butterfield et al., 1994-Sergeev, p. 214, pl. XVII, Figs. 1 and 2; pl. XIX, Fig. 10; pl. XXII, Figs. 1, 2, 7, 8, 11, 12; pl. XXV, Fig. 9; pl. XXVIII, Fig. 2; pl. XLIII, Fig. 7; pl. XLIV, Figs. 8 and 12.

Material: More than 30 specimens in various state of preservation; solitary and in clusters of filaments preserved incompletely and fragmented at different length.

Description: Filamentous sheaths, simple, tubular in shape, with psilate surface and of an equal cross-section diameter along the filament length. One termination of the sheath is rounded (the only preserved) but most terminations are broken apart. No cell remnants preserved and sheaths seem to be empty inside.

Dimensions: $N=12$. The cross-section diameter of sheath is $6-8 \mu \mathrm{m}$; the length of filament fragments preserved is $80-210 \mu \mathrm{m}$.

Present record: Łopiennik IG-1 borehole at a depth of 5376.7, 5382.2 and $5385.6 \mathrm{~m}$, Włodawa Formation, upper Ediacaran.

Occurrence and stratigraphic range: Worldwide occurrence of the species in a stratigraphic range from Mesoproterozoic, ca. $1650 \mathrm{Ma}$ (Sergeev, 2006), to terminal Ediacaran, ca. $545 \mathrm{Ma}$ (present record), spanning approximately $1100 \mathrm{Ma}$

Genus Timofeev and Hermann, 1976, emend. Butterfield et al., 1994

Type species: Tortunema wernadskii (Shepeleva, 1960) Butterfield, 1994; Russia, East European Platform, Leningrad (=St.Petersburg) area, Smerdovitsy 3 borehole, at a depth of 211.5-381.0 m, Gdovsk beds to "Blue clays" beds, Lower Cambrian (Shepeleva, 1960, p. 170; Butterfield et al., 1994, p. 68); the re-interpreted stratigraphic position of the holotype is in the Gdovsk Formation, Upper Vendian, i.e. Ediacaran (Kolosov, 1984; and herein).

Synonymy:

Pro parte 1960 Oscillatorites Wern.-Shepeleva, p. 170.

1960 Oscillatorites Wernadskii sp. nov.-Shepeleva, pp. 170-171, Fig. 1 (=Tortunema). Pro parte 1976 Tortunema Hermann gen.n.-Hermann in Timofeev and Hermann, p. 39.

Non 1976 Tortunema eniseica Hermann gen. et. sp. n.-Hermann in Timofeev and Hermann, p. 40, pl. 12, Fig. 4 (=Siphonophycus).

Non 1980 Tortunema bothnica n.sp.-Tynni and Donner, p. 16, pl. VII, Figs. 73-76 (=Siphonophycus).

1979 Botuobia Pjatiletov gen.n.-Pyatiletov, pp. 714-716.

Pro parte 1980 Oscillatoriopsis Schopf, 1968-Tynni and Donner, p. 15

1980 Oscillatoriopsis bothnica n.sp.-Tynni and Donner, p. 15, pl. VII, Fig. 83. (=Tortunema).

1980 Oscillatoriopsis constricta n.sp.-Tynni and Donner, p. 15, pl. VII, Figs. 82, 85, 86 (=Tortunema).

Pro parte 1982 Palaeolyngbya Schopf, 1968-Kolosov, pp. 72-73.

1982 Palaeolyngbya zhedaica Kolosov, sp. nov.-Kolosov, p. 72, pl. IX, Fig. 2 (=Tortunema).
1982 Palaeolyngbya patomica Kolosov, sp. nov.-Kolosov, pp. 72-73, pl. X, Fig. 1 (=Tortunema).

1984 Botuobia Pjatiletov, 1979, emend.-Kolosov, p. 43.

Pro parte 1989 Oscillatoriopsis Schopf, 1968-Jankuskas et al., p. 116.

1989 Oscillatoriopsis angusta (Kolosov, 1984) comb. nov.-Jankauskas et al., p. 116 (=Tortunema).

1989 Botuobia Pjatiletov, 1979-Jankauskas et al., p. 100.

1989 Tortunema Hermann, 1976, emend. Hermann-Jankauskas et al., p. 123.

1992 Tortunema Hermann (=German), 1976-Schopf, p. 1089.

1994 Tortunema Hermann, 1976, emend.-Butterfield et al., pp. 67-68.

Remarks: The genus Tortunema was established for septate (pseudoseptate), Sshaped to looped filaments with tapering terminations, width of trichomes $10-25 \mu \mathrm{m}$, and length of cells three to four times smaller than the width (the latter dimension is calculated to be 3-6 $\mu \mathrm{m}$ ), (Hermann in Timofeev and Hermann, 1976, p. 39). The holotype of the type species, T. sibirica Hofmann, 1976 (in Timofeev and Hermann, 1976, pl. 12, Fig. 2; re-photographed in Schopf, 1992, pl. 28E), shows the pseudoseptate filament with lines defining annular segments, which are distinctive near to the narrower, rounded terminations but diminishing and passing into simple tubular portion in the central part of the specimen. Butterfield et al. (1994) emended the genus diagnosis to pseudoseptate, filamentous sheaths with thin annular lines or thickenings, forming regular annulations, but lacking true cellular preservation, in which the position of trichome septa/cell septa is only impressed on the extracellular sheath. They regarded the filament S-shape a taphonomic feature and excluded it from the diagnosis, and the terminal narrowing of the filament to be non-diagnostic for the genus, being rather of a taphonomic origin or having an intraspecific significance. Butterfield et al. (1994) recognized the other species, $T$. Wernadskii (Schepeleva, 1960) $\mathrm{n}$. com., as having priority to be the type species of their emended genus, by including into this genus as a junior synonym Botuobia Pjatiletov, 1979. This taxonomic interpretation followed the transfer of Oscillatorites wernadskii Shepeleva, 1960 to Botuobia wernadskii (Shepeleva, 1960) Kolosov, 1984, comb. nov., which became a senior synonym of Botuobia vermiculata Pyatiletov, 1979, the type species of Botuobia Pyatiletov, 1979, and replaced it (Kolosov, 1984; Jankauskas et al., 1989). The genus Tortunema resembles in the overall habit also the genus Oscillatoriopsis Schopf, 1968, but it differs primarily because the latter taxon is truly cellular and smaller in trichome width.

Tortunema wernadskii (Shepeleva, 1960) Butterfield, 1994 (Fig. 5D)

Synonymy:

1960 Oscillatorites Wernadskii sp.nov.-Shepeleva, pp. 170-171, Fig. 1

1976 Tortunema sibirica gen. et sp. n.-Hermann in Timofeev and Hermann, p. 40, pl. XII, Figs. 2 and 3.

1979 Botuobia vermiculata Pjatiletov, sp.n.-Pyatiletov, p. 716, Fig. 1. (Observe misspelled name epithet as "vermicalata" in figure caption).

1980 Oscillatoriopsis bothnica n.sp.-Tynni and Donner, p. 15, pl. VII, Fig. 83. (Observe misspelled name epithet as "bottnica" in figure caption).

1980 Oscillatoriopsis constricta n.sp.-Tynni and Donner, p. 15, pl. VII, Figs. 82, 85, 86. Non 1980 Tortunema bothnica n. sp.-Tynni and Donner, p. 16, pl. VII, Figs. 73-76 (=Siphonophycus).

1982 Tortunema sibirica Hofmann, 1976-Jankauskas, p. 114, pl. XLIII, Fig. 7; pl. XLVIII, Fig. 2; non pl. XXXVIII, Fig. 7; non pl. XLIII, Fig. 9.

1982 Palaeolyngbya zhedaica Kolosov, sp.nov.-Kolosov, p. 72, pl. IX, Fig. 2a,b.

1984 Botuobia vermiculata Pyatiletov, 1979-Kolosov, pp. 43-44, pl. VII, Fig. 2.

1984 Botuobia wernadskii (Schep.), 1960-Kolosov, pp. 44-46, pl. VII, Fig. 3.

1984 Botuobia immutata Kolosov, sp. nov.-Kolosov, p. 46, pl. VIII, Fig. 1.

1988 Tortunema cellulaefera Pjatiletov, sp. nov.-Pyatiletov, pp. 79-80, pl. VII, Figs. 3 and 4

1989 Botuobia wernadskii (Shepeleva, 1960) emend. Kolosov, 1984, comb. nov.-Jankuskas et al., p. 101, pl. XXVI, Figs. 1 and 2; pl. XLIII, Fig. 1.

1989 Tortunema sibirica Hofmann, 1976, emend. Hermann-Jankauskas et al., p. 123, pl. XXIX, Figs. 2, 4, 6 and 10

1992 Tortunema sibirica Hermann (=German) 1976 (in Timofeev and German 1976)-Schopf, p. 1089, pl. 28 E (holotype re-photographed), $F_{1}, F_{2}$ (paratype rephotographed).

1992 Oscillatorites wernadskii Shepeleva, 1960 (Yankauskas, in press)-Schopf, p. 1115 , pl. $54 \mathrm{~J}$.

1994 Tortunema Wernadskii (Shepeleva, 1960) Butterfield, n.comb.-Butterfield et al., p. 69 , Figs. $24 \mathrm{H}$ and $27 \mathrm{~A}-\mathrm{C}$.

Material: Five specimens, relatively well preserved.

Description: Filamentous, thin-walled, pseudoseptate sheaths with annular segments defined by thin lines, which do not form any relief or constriction on the sheath surface. The annular segments are rectangular in shape on the sheath surface and of equal dimensions. The sheath width is constant along the filament length. The sheath terminations are not preserved in the material studied. No cell remnants observed.

Dimensions: $N=5$. The sheath width is $16-20 \mu \mathrm{m}$, the length of annular segments 4-5 $\mu \mathrm{m}$.

Remarks: Butterfield et al. (1994) preserved the original spelling of the specific epithet Wernadskii by Shepeleva (1960), however, although it derives from the family name it could be transcribed with the lower case in binominal taxonomic nomencla- 
ture. This original spelling is preserved in the synonymy and citations, but adjusted in the following text. The phonetic transcription of author's name Shepeleva was incorrectly transliterated as Schepeleva in Kolosov (1984), Jankauskas et al. (1989) and Butterfield et al. (1994), but the original printing is also kept in the synonymy and citations.

The stratigraphic range of the species wernadskii established in the interval ranging from the Gdovsk beds to the "Blue clays" in the Smerdovitsy 3 borehole (211.5-381.0 m) was considered by Shepeleva (1960) to be lower Cambrian. The Gdovsk Formation is referred to the Upper Vendian, whereas the "Blue clays", first included into the Lontova Formation (Volkova, 1968) and subsequently subdivided into the Lontova Formation (lower "Blue clays") and the Lükati Formation (upper "Blue clays"), to the lower Cambrian (Volkova et al., 1979). There is no indication from which portion of the strata the holotype is derived and thus from which formation.

Kolosov (1984, pp. 44-45) ascribed the occurrence of Shepeleva's holotype of Oscillatorites wernadskii, under a new combination of Botuobia to the Vendian strata and quoted it as deriving from the "Gdovsk Formation of the Valdai Series", although the source of such information is unknown. Jankauskas et al. (1989) followed this taxonomic combination and stratigraphic interpretation, whereas Butterfield et al. (1994) cited the relative age of the holotype after Shepeleva (1960) to be early Cambrian for their new combination of the species. The inferred stratigraphic position of the holotype by Kolosov (1984) is accepted here because the number of microscopic slide containing it suggests the lower portion of the rock succession, i.e. the Gdovsk Formation.

Present record: Łopiennik IG-1 borehole at a depth of $5385.6 \mathrm{~m}$, Włodawa Formation, upper Ediacaran.

Occurrence and stratigraphic range: Russia, St.Petersburg area, East European Platform, Smerdovitsy 3 borehole, $211.5 \mathrm{~m}$, "Blue clays" beds, lower Cambrian (Shepeleva, 1960), however, the relative age of this occurrence has been revised by Kolosov (1984) as latest Ediacaran; Yakutia, eastern Siberian Platform, Krasnogorsk region, Turukhansk area, Miroedikha River section, Miroedikha Formation, Upper Riphean (Timofeev and Hermann, 1976; Jankauskas et al., 1989; Schopf, 1992) southern Siberian Platform, Peleduy 750 borehole, 1794.5 m, Bochugunorsk Formation, Vendian, Yudomian Stage (Pyatiletov, 1979; re-named for the Ozernaya 750 borehole, Kursovsk Formation according to Kolosov, 1984). Finland, Hailuoto Island Hailuoto 1 and 2 drillcores, 57.4 and 59.3 m, respectively, Muhos Formation, Upper Precambrian (Tynni and Donner, 1980): Southern Urals, Bashkiria, Kabakovo 62 borehole, 3526.0-3528.0 m, Lemeza River section, Zilmerdak Formation, Bolshoy Shishenyak River, Podinzirsk Formation, Zilim River, Uksk Formation, Upper Riphean (Jankauskas, 1982); eastern and southern Siberian Platform, Lena River section at Macha village, Tinnov Formation, Upper Proterozoic (Kolosov, 1982), and several subsurface successions, Kursovsk and Iktekh formations, Vendian (Kolosov, 1984); northeastern Spitsbergen, Geerabukta locality, Svanbergfjellet Formation, Algal Dolomite Member, Neoproterozoic, ca. 700-800 Ma (Butterfield et al., 1994).

The biochronological range of Tortunema wernadskii is ca. $850-545 \mathrm{Ma}$. It is bracketed by the broadly estimated age of the Miroedikha Formation (Mendelson and Schopf, 1992), and the present record.

Domain Eucarya Woese, Kandler and Wheelis, 1990

Kingdom Protoctista Margulis et al., 1989

Phylum Chlorophyta Margulis et al. 1989

Class Chlorophyceae Kützing, 1845

Order Chlorococcales Fritsch, 1935

Family Chlorococcaceae Blackman and Tansley, 1902

Genus Leiosphaeridia Eisenack, 1958, emend. Downie and Sarjeant, 1963

Type species: Leiosphaeridia baltica Eisenack, 1958; Estonia, Ordovician, Ashgill (Eisenack, 1958, p. 8, pl. 2:5)

Synonymy: See for extended synonymy Jankauskas et al. (1989, p. 69) and Fensome et al. (1990, pp. 271-272). Additionally:

1984 Dichotisphaera gen. nov.-Turner, pp. 107-108.

1990 Leiosphaeridia Eisenack, 1958, emend. Downie and Sarjeant, 1963, emend.

Turner, 1984-Fensome et al., pp. 271-272.

1998 Dichotisphaera Turner, 1984-Moczydłowska, p. 81.

Pro parte 1992 Chuaria ("Chuaria jacutica Timofeev, in press"=Leiosphaeridia jacutica)-Schopf, p. 1075

1994 Leiosphaeridia Eisenack, 1958-Butterfield et al., p. 40.
Remarks: The form genus Leiosphaeridia embraces a large group of spheroidal, morphologically simple microfossils, which lack ornamentation and phenetically diffe only in their wall thickness and vesicle diameter. The wall ultrastructure, which may reveal various biological affinities of leiosphaerids and allow their meaningful taxonomic segregation, is known at the moment in a very few morphotypes (Talyzina and Moczydłowska, 2000; Javaux et al., 2004). This mostly non-diagnostic morphology and lack of objective features in leiosphaerids resulted in application of arbitrary chosen size classes, together with approximate wall thickness, to define various species. There is no strict and natural division observed in the size frequency distribution in the published hitherto histograms from Proterozoic populations of leiosphaerids. The Proterozoic form species proposed by Jankauskas et al. (1989) and followed by Butterfield et al. (1994) are in principle split by the size limit of $70 \mu \mathrm{m}$ of vesicle diameter, for groups with thin versus thick vesicle wall.

Extremely abundant leiosphaerid collection (over 23,000 specimens observed) from the transitional Ediacaran-Cambrian successions on the EEP in Poland, and including the present material, displayed variation of vesicle diameter between 10 and $330 \mu \mathrm{m}$, in both thick and thin walled specimens (Moczydłowska, 1991). Although the species have not been recognized, they represent the same morphotypes as described from much older Svanbergfjellet Formation of Spitsbergen by Butterfield et al. (1994). In the present study only two species are identified although the association consists of several morphological variants and is probably biologically multispecific.

Fensome et al. (1990, p. 274) proposed a new combination $L$. crassa (Pykhova, 1973) comb. nov., which is a homonym of $L$. crassa (Naumova, 1949) Jankauskas, 1989, and L.jacutica (Timofeev, 1966) comb. nov. (Fensome et al., 1990, p. 279), which is a junior synonym of L. jacutica (Timofeev, 1966) Mikhailova and Jankauskas, 1989 (in Jankauskas et al., 1989).

Leiosphaeridia crassa (Naumova, 1949) Jankauskas, 1989 (Figs. 7 and 8 Figs. 7A and 8G)

Synonymy: See comprehensive synonymy by Jankauskas et al. (1989), p. 75. Additionally:

1949 Leiotriletes crassus-Naumova, p. 55, pl. I, Fig. 3.

1989 Leiosphaeridia crassa (Naumova, 1949), emend. Jankauskas, comb.nov.-Jankauskas et al., 1989, p. 75-76, pl. IX, Figs. 5-10.

Non 1990 Leiosphaeridia crassa (Pykhova, 1973) comb. nov.-Fensome et al., p. 274. 1994 Leiosphaeridia crassa (Naumova, 1949) Jankauskas, 1989-Butterfield et al., pp. $40-42$, Fig. 16F, non Fig. 16K.

2005 Leiosphaeridia crassa (Naumova, 1949) Jankauskas in Jankauskas et al. 1989-Grey, p. 179-182, Figs. 63A-C, 64A-D.

2006 Leiosphaeridia crassa (Naumova) emend. Jankauskas, 1989-Sergeev, p. 223. Material: Numerous (over 50 ) well preserved specimens.

Description: Spheroidal and relatively thick-walled vesicles with psilate surface. No excystment observed.

Dimensions: $N=25$. Vesicle cross-section diameter is $25-56 \mu \mathrm{m}$

Present record: Łopiennik IG-1 borehole at a depth of 5376.7, 5382.2 and $5385.6 \mathrm{~m}$, Włodawa Formation, upper Ediacaran.

Occurrence and stratigraphic range: Worldwide distribution in the Middle Proterozoic (Lower Riphean) to lower Cambrian strata, ca. 1650-535 Ma (Naumova, 1949; Jankauskas et al., 1989; Butterfield et al., 1994; Grey, 2005; Sergeev, 2006).

Leiosphaeridia minutissima (Naumova, 1949) Jankauskas, 1989 (Fig. 8H)

Synonymy: See comprehensive synonymy by Jankauskas et al., 1989, pp. 79-80. 1949 Leiotriletes minutissimus-Naumova, p. 52-53, pl. I, Fig. 1.

1989 Leiosphaeridia minutissima (Naumova, 1949), emend. Jankauskas, comb.nov.-Jankauskas et al., 1989, pp. 79-80, pl. IX, Figs. 1-4, 11

2005 Leiosphaeridia minutissima (Naumova, 1949) emend. Jankauskas in Jankauskas et al., 1989-Grey, p. 184, Fig. 63D.

Material: More than 30 well preserved specimens

Description: Spheroidal, thin-walled vesicles with psilate surface. No excystment observed.

Dimensions: $N=20$. Vesicle cross-section diameter is $34-55 \mu \mathrm{m}$.

Present record: Łopiennik IG-1 borehole at a depth of 5376.7, 5382.2 and $5385.6 \mathrm{~m}$, Włodawa Formation, upper Ediacaran.

Occurrence and stratigraphic range: Estonia, lower Cambrian, Lontova Formation (Naumova, 1949). Moscow Syneclise, Middle Proterozoic, Riphean, Pachelma Series; Peri-Urals, Bashkiria, Vendian, Redkino regional stage; Lithuania, Lakay Formation, middle Cambrian (Jankauskas et al., 1989). Australia,Centralian Superbasin, 

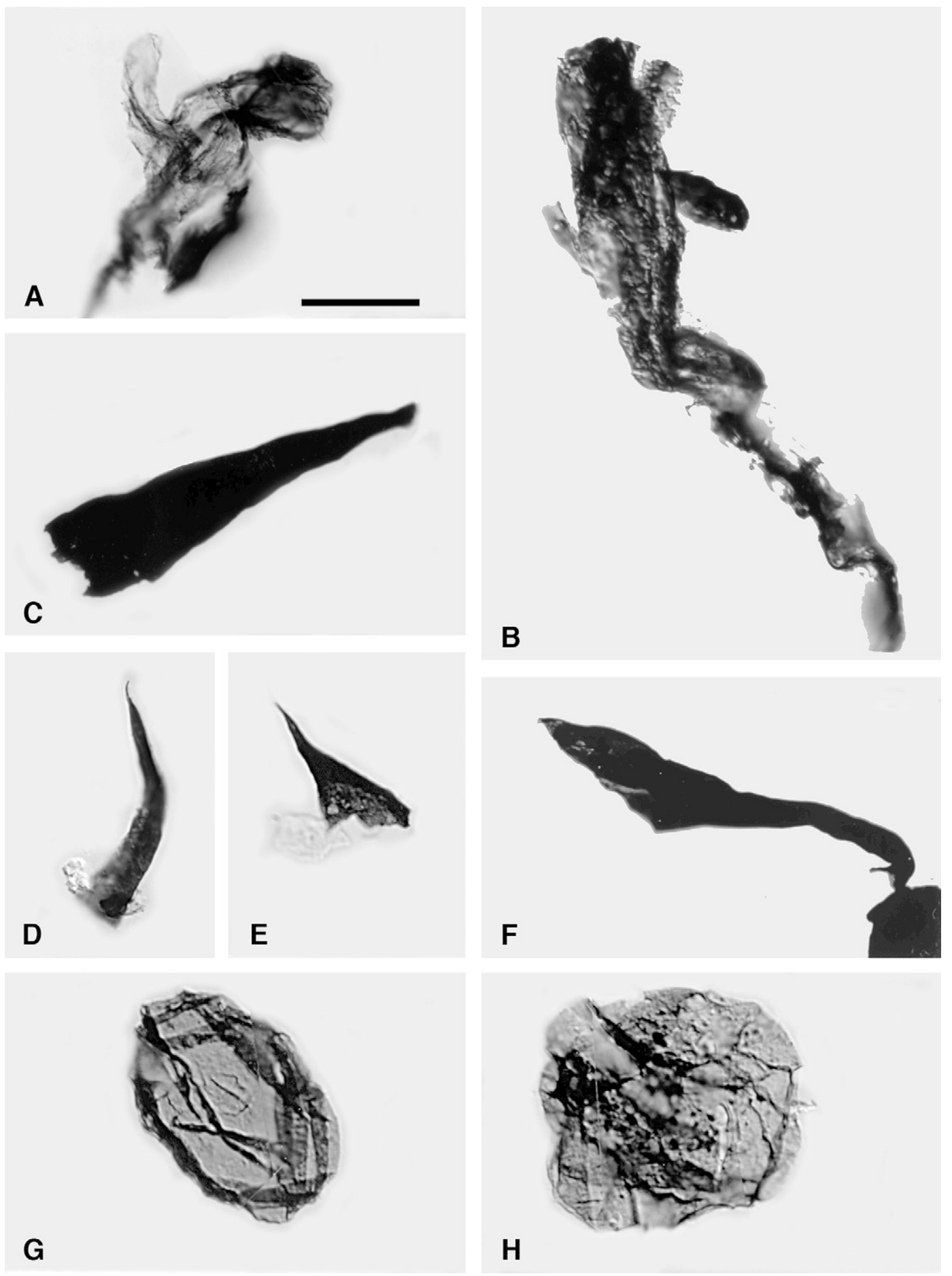

Fig. 8. (A and B) Valkyria borealis Butterfield, 1994. (A) Specimen ME-Pl-05/3.K/27/2. (B) Specimen ME-Pl-05/3.X/45/2. Oval body with lobate lateral extensions. (C-F) Ceratophyton vernicosum Kirjanov, 1979. (C) Specimen ME-Pl-05/3.Y/28/4. (D) Specimen ME-Pl-05/2.X/35/2. (E) Specimen ME-Pl-05/3.U/38/4. (F) Specimen ME-Pl-05/3.M/48/1. (G). Leiosphaeridia crassa (Naumova, 1949) Jankauskas, 1989. Specimen ME-Pl-05/3.W/4872. (H) Leiosphaeridia minutissima (Naumova, 1949) Jankauskas, 1989. Specimen ME-Pl-05/2.T/38/1. (A-C, E, F and G) Sample from a depth of $5376.7 \mathrm{~m}$; (D and H) Sample from a depth of $5382.2 \mathrm{~m}$. Scale bar in A equals $30 \mu \mathrm{m}$ for A, B, and D; $45 \mu \mathrm{m}$ for C and $\mathrm{F} ; 40 \mu \mathrm{m}$ for $\mathrm{E} ; 20 \mu \mathrm{m}$ for $\mathrm{G}$ and $\mathrm{H}$.

Cryogenian to Ediacaran (Grey, 2005). The total species range is ca. 725-500 Ma (Mendelson and Schopf, 1992; Gradstein et al., 2004).

Domain Eucarya Woese, Kandler and Wheelis, 1990 Incertae sedis

Genus Ceratophyton Kirjanov, 1979

Type species: Ceratophyton vernicosum Kirjanov, 1979; Ukraine, Volhyn region, Bolshoy Obzyr 5 borehole at a depth of $154.0 \mathrm{~m}$, Stokhod Formation, lower Cambrian,
Lontova regional stage (Kirjanov in Volkova et al., 1979; p. 35, pl. 38, Fig. 3 holotype). Synonymy:

1979 Ceratophyton Kirjanov, gen. nov.-Kirjanov in Volkova et al., p. 35. 1980 Cerattophyton (sic) Kirjanov, 1979-Paskevicienè, pp. 46-47.

\section{Ceratophyton vernicosum Kirjanov, 1979 (Fig. 8C-F)}

Synonymy:

1968 "Problematic plant remains"-Kirjanov, pl. 5, Figs. 18-20. 


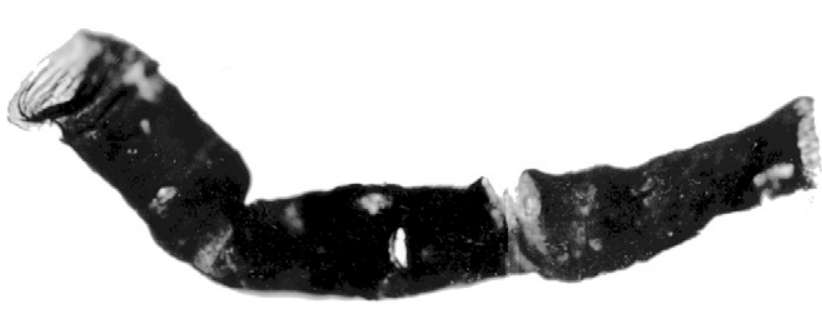

A

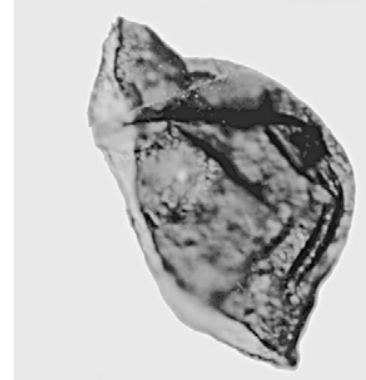

B

Fig. 9. (A) Rugosoopsis tenuis Timofeev and Hermann, 1979, emend. Butterfield et al., 1994. Specimen ME-Pl-05/1.M/34. Sample from a depth of 5385.6 m. Plications of the tubular sheath are visible on the specimen left side. (B) Gen. et sp. indet. The organic-walled, umbrella-shaped microfossil. Specimen ME-Pl-05/3.X/28. Sample from a depth of $5376.7 \mathrm{~m}$. Scale bar in A equals $30 \mu \mathrm{m}$ for A and B.

1979 Ceratophyton vernicosum Kirjanov, sp. nov.-Kirjanov in Volkova et al., p. 35, pl. 38 , Figs. $1-3,5,6,10,12$

1980 Ceratophyton vernicosum Kirjanov, 1979-Paskevicienè, p. 47, pl. 8, Figs. 1-3; pl. 11, Fig. 5; pl. 14, Fig. 10.

1981 Ceratophyton vernicosum Kirjanov-Korkutis, p. 82, Fig. 2:7

1983 Ceratophyton vernicosum Kirjanov, sp. nov.-Kirjanov in Volkova et al., p. 43, pl. 38 , Figs. $1-3,5,6,10,12$.

1987 Ceratophyton vernicosum Kirjanov, 1979-Knoll and Swett, p. 922, Fig. 8.2. 1989 Ceratophyton vernicosum Kirjan.-Jankuskas et al., pl. 54, Fig. 7 (holotype reproduced).

1989 Ceratophyton groetlingboensis Hagenfeldt n.sp.-Hagenfeldt, 1989, pp. 28-29 pl. 1, Fig. 9 (holotype)-10.

1991 Ceratophyton vernicosum Kirjanov-Moczydłowska, p. 12, pl. 15E

2001 Veryhachium (Veryhachium) trisentium Zang, sp. nov.-Zang, p. 84, pl. III, Fig. 6 (holotype)-7.

Material: Seven specimens relatively well preserved although with one termination broken apart.

Description: Organic-walled, conical microfossils with thick, smooth to fibrous wal surface, hollow inside, tapering gradually to narrow and sharp-pointed termination and having widely open opposite ending with irregular edge, probably broken off from a larger body.

Dimensions: The length of partially preserved specimens exceeds $100-200 \mu \mathrm{m}$, the width of widened termination varies between 20 and $63 \mu \mathrm{m}(N=7)$.

Remarks: The conical specimens are often curved or deformed at narrow termination showing that the organic matter of the wall is plastic and resilient although the walls are thick and appear to be fibrous.

Kirjanov (1968, in Volkova et al., 1979) described the microfossil as problematic plant remains and probable being preserved fragmentary because the widened parts of the specimens are usually broken. Knoll and Swett (1987) treated Ceratophyton vernicosum as microorganism incertae sedis and of unclear taxonomic affinities and, similarly, being a portion of a larger body. Mendelson and Schopf $(1992$, p. 884, 945) interpreted the specimen illustrated by Knoll and Swett (1987) to be a degraded tubular sheath of filamentous prokaryote or a fragment of sapropel, whereas specimens reported by Kirjanov in Volkova et al. (1979) as "possibly of animal rather than plant origin". The specimen in question from Spitsbergen (Knoll and Swett, 1987) is considered herein conspecific with $C$. vernicosum and included in its synonymy. There is no morphological feature preserved in any record to provide a clear indication neither of plant nor animal affinities, however, the optical appearance of the wall organic matter and the resistance to chemical preparation suitable for extraction of sporopollenin-like microfossils may suggest that the specimens have plant-like chemistry. Chitin, which is a chemical polymer synthesized by animals of various clades and used for example to excrete cuticle as well as by fungi in forming the cell wall, is also resistant to chemical maceration. Although chitin could not be preserved in such old rocks otherwise as its derivative (Traverse, 2007), it could not be excluded to form originally the wall of Ceratophyton.
The other species known, C. duplicum Paskevicienè, 1980, was described from the lower Cambrian Lontova Formation of Latvia. It differs from $C$. vernicosum by having a double wall and appearing as a cone-in-cone structure but is of the same overall size range and shape. The internal cone-shaped vesicle is distantly located from the outer wall and may represent the part of the body, which is not preserved in the specimens attributed to $C$. vernicosum. Both forms may represent preservation variants of the same species.

Ceratophyton groetlingboensis Hagenfeldt, 1989, is a junior synonym of $C$. vernicosum, as is Veryhachium (Veryhachium) trisentium Zang, 2001. The latter species has been described as possessing three processes extending from the central triangular vesicle without obvious boundary between the processes and central body, and in that way differing from C. vernicosum (Zang, 2001). The overall habit of the specimens illustrated is typical for that of Ceratophyton but not Veryhachium, and the presence of an open termination at the wider side of the vesicle definitely excludes it from Veryhachium. Because the edge around the open termination is irregular and probable broken, it may mimic the presence of processes.

Present record: Łopiennik IG-1 borehole at a depth of 5382.2 and $5376.7 \mathrm{~m}$, Włodawa Formation, upper Ediacaran.

Occurrence and stratigraphic range: The Ukraine, Latvia, Lithuania, Belarus, Russia, lower Cambrian, Rovno and Lontova regional stages (Kirjanov in Volkova et al., 1979; Paskevicienè, 1980; Korkutis, 1981; Jankauskas et al., 1989; but the lower part of the Rovno stage is referred to the terminal Vendian = Ediacaran, see Moczydłowska 1991); Vendian (Jankauskas et al., 1989). Poland, Lublin Slope of the East European Platform, Łopiennik IG-1 borehole at a depth of 5210.0 and $5197.2 \mathrm{~m}$, Mazowsze Formation, lower Cambrian, Platysolenites and Schmidtiellus zones, respectively; Kaplonosy IG-1 borehole at a depth of 1314.0 and 1293.0 m, Mazowsze Formation, Platysolenites Zone (Moczydłowska, 1991). Sweden, Island of Gotland, Grötlingbo1 borehole, File Haidar Formation, lower Cambrian, Schmidtiellus-Holmia inusitat zones (Hagenfeldt, 1989). Spitsbergen, Andromedafjellet and South Tokammane nunataks, Tokammane Formation, lower Cambrian correlative with the Lontova stage and Holmia zone (Knoll and Swett, 1987). South Australia, Arrowie Basin, Old Motpena 1 borehole, at 474.5, 479.7, 480.0 m, Parachilna Formation, lower Cambrian, zone 3; Yalkalpo 2 borehole, at 780.0 and $782.7 \mathrm{~m}$, lower Wilkawillina Limestone, lower Cambrian, zone 5 Skiagia ciliosa (Zang, 2001; Zang et al., 2007).

Genus Valkyria Butterfield, 1994

Type species: Valkyria borealis Butterfield, 1994 in Butterfield et al. (1994), pp. 26-29, Figs. 9A-E, 10A-H, 11; Spitsbergen, Geerabukta locality, Svanbergfjellet Formation, Algal Dolomite member ( $55 \mathrm{~m}$ above base), Neoproterozoic, $\mathrm{ca} .700-750 \mathrm{Ma}$ (Butterfield et al., 1994). By original designation.

\section{Valkyria borealis Butterfield, 1994 (Fig. 8A and B)}

Synonymy:

1994 Valkyria borealis Butterfield, n. sp.-in Butterfield, Knoll and Swett, pp. 26-29, Figs. 9A-E, 10A-H, 11 
Material: Two specimens relatively well preserved; one specimen is fully preserved although collapsed and distorted at one termination and the other is fragmentary. Description: Thin-walled, elongated, oval main body with rounded terminations and bearing a few lobate lateral extensions (1-4 preserved), which are freely connected to the inner cavity of the main body and arise directly from its wall without any constriction. The wall surface is psilate and some compression folds of the wall occur on the main body and the lobes. No internal structure is preserved, except of a fragment of longitudinal medial strip.

Dimensions: $N=2$. The length of main body is over $63 \mu \mathrm{m}$, and its width is $17-20 \mu \mathrm{m}$. The lateral lobes are $15-65 \mu \mathrm{m}$ in length and $8-9 \mu \mathrm{m}$ in width. The dimensions are within the size range of the type material.

Remarks: The present record is the first outside the type locality and in strata of much younger age, extending the species stratigraphic range substantially.

Present record: Łopiennik IG-1 borehole at a depth of $5376.7 \mathrm{~m}$, Włodawa Formation, upper Ediacaran.

Occurrence and stratigraphic range: Spitsbergen, Geerabukta locality, Svanbergfjellet Formation, Algal Dolomite member ( $55 \mathrm{~m}$ above base), Neoproterozoic, ca. 700-750 Ma (Butterfield et al., 1994).

The age of the species is $\mathrm{ca}$. 750-545 Ma, and its longevity is approximately $200 \mathrm{Ma}$.

\section{Genus et species indet. (Fig. 9B)}

Material: A single, well preserved specimen.

Description: Organic-walled microfossil in overall shape of a semi-spherical bowl with thin wall and sharp-lined edge of the opened side. The surface is smooth to chagrin (probably corroded), covered by irregular, delicate compression folds randomly distributed. The edge of the open side is slightly undulating.

Dimensions: Length along the opened side is $65 \mu \mathrm{m}$, width measured perpendicularily to the opened side from the top to the edge is $38 \mu \mathrm{m}$.

Present record: Łopiennik IG-1 borehole at a depth of 5376.7 m, Włodawa Formation, upper Ediacaran.

\section{Dividing cell (Fig. 7B)}

Material: A single, well preserved specimen.

Description: Two semi-spheroidal cells attached by a common and not fully separated wall, having the voids of cells connected freely. The wall surface is psilate. Dimensions: The diameter of the daughter cells is $24-26 \mu \mathrm{m}$, the total length of the specimen is $47 \mu \mathrm{m}$.

Remarks: The specimen shows the cell fission of a smooth-walled mother cell into elongated and semi-spheroidal daughter cells with incompletely separated cell wall between them. Presumably cytoplasm connected them while alive. The simple morphology of a single specimen prevents any certain identification of the fossil taxon and comparison to modern counterparts. The size range of the daughter cells at this early phase of cytokinesis, before separating and growing to a mature and full size characteristic of the species, indicates convincingly that this was an eukaryotic organism. The cell division in preservable cyanobacteria may only be apparently similar and their cell dimensions and wall thickness are smaller. Optically, the microscopic appearance of the cell wall in cyanobacteria is different although it is not objectively describable. It may be seen for example in dyads of Eoentophysalis (Fig. 8D), or in Sphaerophycus or Myxococoides (Butterfield et al., 1994, Figs. 20M and $\mathrm{J}$, respectively). Because of such microscopic observations, the present microfossil seems not to be prokaryotic.

Several instances of dividing sphaeromorphic cells arrested at various phases of the process have been reported and attributed to as acritarchs, generally leiosphaerids, or some species of the genus Leiosphaeridia (Jankauskas et al., 1989, pl. 8, Figs. 13, 14, 16; pl. 17, Figs. 1-3, 5, 7; Moczydłowska, 1991, pl. 13, Figs. E-G). The assignment to acritarchs equales with the assumption that the vesicles undergoing division were unicellular protoctists (Knoll, 1994), probably algal, and in a case of some leiosphaerids of prasinophycean or chlorophycean (Talyzina and Moczydłowska, 2000) or vaucheriacean affinities (Butterfield, 2004). Morphological resemblance and consistency with cell diameter of some stages in the life cycle of Jacutianema solubila (Butterfield, 2004, Figs. 4F, 5B, 12) may not exclude the possibility that the present microfossil is a secondary Gongrosira-phase cyst of this vaucheriacean alga. However, because of a great variety of vegetative and resting stages of $J$. solubila and other microbiota, which could be preserved as simple, morphologically convergent fossil form-taxa (Butterfield, 2004), and because this is a single specimen, this affiliation remains speculative. Regardless of a possible closer biological affinity of the microfossil in question, its eukaryotic origin is supported by the cells size and the phase of cytokinesis with partially constricted cell wall to form a cleavage furrow dividing mother cell into two lobes, resembling anaphase before division of the cytoplasm. This arrested cytokinesis differs from fission of cells or budding in prokaryotes, also known in fossil records (Hofmann, 1976; Golubic and Hofmann, 1976; Golubic, 1999b), but is similar to eukaryotic cell division (Butterfield, 2004; Glotzer, 2005).

Present record: Łopiennik IG-1 borehole at a depth of $5376.7 \mathrm{~m}$, Włodawa Formation, upper Ediacaran.

\section{Biological affinities and life habitats}

The prokaryotic and eukaryotic level of organization is recognized in the microbiota described and their affinities to extant phyla, classes and orders are convincingly established for most taxa by means of comparative morphology, palaeoecology, and in some instances, biogeochemistry and ultrastructure of cell wall. The affiliation of three taxa, Valkyria, Ceratophyton and gen. et sp. indet. remains uncertain and they are treated as incertae sedis microfossils. It is however accepted that the former two are complex eukaryotic organisms with certain features that may suggest multicellularity or even a metazoan origin (Butterfield et al., 1994; Mendelson and Schopf, 1992). The natural systematics and phylogenetic relationships of the microbiota lie outside the scope of the present discussion but are relevant, even in more general terms, for recognising their basic ecological requirements and the continuity of certain evolutionary lineages throughout the Cryogenian Period into the Ediacaran. Understanding the mode of life, nutrition and reproduction cycles of these microbiota will constrain the critical minimum conditions enabling them to survive, reproduce and maintain viable populations through extended period of environmental perturbation.

Two of the Domains of life, Bacteria and Eucarya, are represented by several species in the Lublin association. Bacteria, including cyanobacteria, are prokaryotic, single-celled to multicellular filamentous organisms that reproduce asexually, whereas Eucarya embrace both single-celled and multicellular eukaryotes, having sexual reproduction cycles and being obligatory/facultative aerobes.

The eukaryotic algal affinity of several representative specimens of the genus Leiosphaeridia has recently been well supported by ultrastructural studies of the cell wall (Talyzina and Moczydłowska, 2000; Arouri et al., 2000; Javaux et al., 2004), but it has also been assumed on the basis of morphology, size, chemically resistant sporopollenin-like biopolymers of the cell wall and palaeoecologic distribution (Tappan, 1980; Vidal, 1994; Colbath and Grenfell, 1995). Leiosphaerids are conventionally interpreted as cysts, i.e. dormant/reproductive stages in the life cycle of microalgae, and this is well supported by the presence of an excystment opening, comparative morphology, recalcitrant cell wall and their abundance (Vidal and Ford, 1985; Vidal and Moczydłowska, 1997; Butterfield et al., 1994; Javaux et al., 2004; Marshall et al., 2005, 2006). They show a random and widespread distribution in shallow marine sediments, which is consistent with a planktic mode of life and accumulation of resting cysts in seafloor sediments across shelves and open-marine facies. Butterfield and Chandler (1992) suggested that some leiosphaerids might have been benthic because they occur "as discrete localized populations" in the investigated sites. The record on which this assumption was based is understood here as an incidental accumulation of microfossils but not reflecting natural populations of microbiota, thus not proving their benthic mode of life. 
Ultrastructural studies of the cell wall of the early Cambrian Leiosphaeridia spp. from the Lükati Formation in the EEP in Estonia, Tallinn, demonstrated an affinity to green algae from the Class Chlorophyceae, Order Chlorococcales (Talyzina and Moczydłowska, 2000). The observed composite multilayered wall ultrastructure, with trilaminar sheath structure (TLS) of the external layer, is diagnostic for many green algae and it is the best hitherto obtained evidence to establish the affiliation of these microfossils. The specimens of Leiosphaeridia spp. examined by Talyzina and Moczydłowska (2000) belong to the same phenetic and size category as Leiosphaeridia minutissima from the present collection and it is concluded that they represent the same species and evolutionary lineage recorded by L. minutissima in the Proterozoic and Cambrian (Fig. 3). Leiosphaeridia crassa, another species in the Lublin association, also possesses the multilayered wall ultrastructure, with a possible although partially preserved TLS observed in specimens from the $1.4-1.5 \mathrm{Ga}$ Roper Group in Australia, and an affinity to green algae (Javaux et al., 2004). Microchemical analysis of three species of Leiosphaeridia (L. crassa, L. jacutica and L. tenuissima) from the same Australian material showed similar chemical composition of their wall (Marshall et al., 2005). Although inconclusive with respect to their systematic relationships, it may suggest that a common biochemical composition (aliphatic sterol algaenan) derives from the same biosynthetic pathway in genetically closely related organisms within the Class Chlorophyceae.

Combined with previous morphological observations, the available evidence indicates that the two classes of the Phylum Chlorophyta, Class Prasinophyceae and Class Chlorophyceae (systematic subdivision according to Margulis et al., 1989) are represented by microfossils identified within the genus Leiosphaeridia (Talyzina and Moczydłowska, 2000).

The green algae (Phylum Chlorophyta) are single-celled to multicellular biota forming thallus (coenocytic to filamentous). They are photoautotrophic, aerobic, planktic or benthic, having complex sexual life cycles with alteration of meiotic and mitotic generations. Without exception, as all members of the Kingdom Protoctista in Domain Eucarya, they are confined to wet habitats and could not otherwise complete their life cycle despite the ability, by some, to produce airborne cysts and spores (Margulis et al., 1989). Chlorophytes occur in almost all habitats (fresh, brackish- and seawater, soil, terrestrial and subaerial) and in extreme conditions (snow, salinas, hot and cold deserts, volcanic ashes and disturbed areas); some are well adapted to survive adverse environmental conditions (Melkonian, 1989). Those from the Class Chlorophyceae are predominantly freshwater today while marine genera and species are less diverse. However, several orders are exclusively marine and can tolerate a great range of salinity (Bold and Wynne, 1985). It is argued that the situation was different during the Proterozoic in that marine chlorophycean algae were abundant and diverse, constituting with bacteria a substantial component of marine phytoplankton. This is seen in the fossil record and is apparent from phylogenetic trees, showing the sequence of evolutionary events in which marine algae derived from photosynthetic cyanobacteria and then later on colonized terrestrial environments and evolved into specialized freshwater species (Sogin, 1994; Hackett et al., 2007).

Leiosphaeridia crassa and L. minutissima from the Lublin association are thus considered to be marine chlorophyceans (and chlorococcaleans in case of the latter species), characterised by photosynthetic nutrition, aerobic respiration, having sexual/asexual cycle of reproduction and a planktic mode of life. As such, they required habitats of well-oxygenated open water in the photic zone and periodic access to the bottom sediment to survive through the Cryogenian Period, as they evidently did.

Valkyria borealis is of particular interest. This is because the species represents presumably eukaryotic, complex and possibly multicellular, and perhaps metazoan organisms (Butterfield et al., 1994), appeared before the Sturtian glacial epoch and lasted to the end of the Ediacaran Period (Fig. 3). It is advanced in functional morphology (having suggested distinct tissue types) and probable behaviour. Such presumably specialized microorganisms, regardless of being autho- or heterotrophic, would have needed more stable environmental conditions for life than less specialized types and more versatile cyanobacteria. The nature of Valkyria, being free-floating or at least occasionally gregarious has not yet been established convincingly. The lack of attachment structures in isolated specimens may suggest a planktic mode of life, although a "colony" of some individuals observed in bedding-parallel thin section has been taken as pointing to a benthic life (Butterfield et al., 1994). In the latter occurrence, three specimens have been reported to be attached to a "poorly defined opaque ovoid" representing a germinating or developing reproductive body, and a gregarious population. This cluster of specimens is not, however, documented by photomicrograph but interpreted by a drawing, and it may indicate instead a random accumulation of discrete specimens around particulate organic matter. In any case, the planktic and/or periodic benthic mode of life of Valkyria would require similar ecological conditions to those of leiosphaerids described above. Accepting entirely benthic adaptation of the species, the habitats would be similar to those of cyanobacteria (see below).

Cyanobacteria of the Lublin association are predominantly filamentous and one species, Eoenthophysalis belcherensis, is coccoid. Their biological affinities are well established to the family level. Eoenthophysalis belcherensis belongs to the Order Chroococcales, Family Entophysalidaceae, and all other species (Fig. 3) to the Order Oscillatoriales, Family Oscillatoriaceae (Schopf, 1968; Hofmann, 1976; Golubic and Hofmann, 1976; Jankauskas et al., 1989; Butterfield et al., 1994; Seong-Joo and Golubic, 1998). All these cyanobacteria are inferred to be photoautotrophic, aerobic, and asexual, although in general the members of the two families are known to be remarkably versatile in their metabolism. Some could survive or even thrive in extreme conditions of temperature range, oxygen content, acidity, UV radiation and desiccation (Schopf, 1999). However, while desiccated their encapsulated spores may survive for perhaps a few tens or hundred of years, as far as is known by comparison to modern counterparts. Oscillatoriaceans must withstand periodic freezing in exposed intertidal environments (Whitton and Potts, 1982), but it happens in seasonal cycles and not over extended periods of time.

The recorded here cyanobacteria lived in benthic communities, on rocky or soft sediment substrate, in marine, tidally influenced habitats. They were microbial mat-builders or dwellers, and required ample water supply and turbulence and/or drainage, regular oxygen supply and sun light for their metabolism (Golubic and Hofmann, 1976; Golubic, 1999a,b; Schopf and Walter, 1982). Such habitats must have been present and ecologically functional throughout the Cryogenian Period.

\section{Longevity of microbiota studied}

Total stratigraphic ranges of microbiota studied, compiled from their global records and combined with isotopic ages of the host strata (Fig. 3), evidently show that they survived the critical intervals of possible Snowball Earth-type glaciations during the Cryogenian Period into the Ediacaran. The longevity of discrete species varies from ca. $400 \mathrm{Myr}$ (Rugosoopsis tenuis) or $150 \mathrm{Myr}$ (Valkyria borealis) to ca. $30 \mathrm{Myr}$ (Ceratophyton vernicosum), but it is substantial for some others where it exceeds $1.1 \mathrm{Ga}$ (Palaeolyngbya catenata) or $1.3 \mathrm{Ga}$ (Eoenthophysalis belcherensis). The modern genus Entophysalis, a counterpart of Eoenthophysalis, is the oldest living fossil, which has presumably maintained its morphology, 
function, life cycle and environmental adaptation throughout more than $1.3 \mathrm{Gyr}$ (Golubic, 1999b). This is not surprising, as many Proterozoic taxa (mostly at a genus level) were long-lived (Schopf and Klein, 1992) showing bradytelic or hypobradytelic rate of evolution characteristic for prokaryotes and some early eukaryotes. Cyanobacteria are among the best examples to fit the Simpson's Rule of the Survival of the Relatively Unspecified (Simpson, 1944) because they are asexual, live in large populations and in a variety of environments (versatility), and this is their successful survival strategy (Schopf, 1999). Regardless of the ancient origins of the biota in the present assemblage, the most significant fact is that so many (as recorded in a single site) morphologically complex and diagnostic morphotypes, and assumed distinct biological species of prokaryotes and some eukaryotes, apparently survived global glaciations.

In the Lublin association these are the cyanobacterial genera, represented by single species, of Palaeolyngbya, Tortunema, Eoschizothrix, Polythrichoides, Rugosoopsis and Eoenthophysalis (Fig. 3). Interestingly, the present record of Eoschizothrix composita, the only known species of the genus (Seong-Joo and Golubic, 1998), is the second one outside the type area and in a stratigraphically distant horizon following almost a $1 \mathrm{Ga}$ time gap. The species has been recently recorded in Ediacaran strata of the Siberian Platform (Sergeev, 2006). Because of the unique morphological traits of the species, the identification of the present specimens is considered certain. This taxon is not widely distributed (three palaeocontinents: North China, Siberia and Baltica), contrary to the other genera mentioned, which are more common or cosmopolitan in Mesoproterozoic and Cryogenian successions worldwide. The two species of Siphonophycus are among the longest lived in the association, but they are less reliable to distinguish as individual biological species because of their simple morphology. Specimens of Siphonophycus may mimic morphologically convergent but different species and be described under a single fossil name or be split into diverse fossil species despite representing dimensionally variable but single biological species. Regardless of the specific diversity, the genus is, however, one of the most common Proterozoic microfossils. It is also frequent in Cambrian strata but it is usually not even reported or studied, if found in younger strata, because of the lack of its importance among newly evolved ornamented microbiota of the time.

The two eukaryotic algal species of the genus Leiosphaeridia in the association are long-lived, spanning a time interval over $1 \mathrm{Ga}$, and extending into the Cambrian. Their specific identification is constrained by similar systematic uncertainties as in the case of Siphonophycus. However, the fact remains that whatever specific diversity is true for Leiosphaeridia and the apparent ranges of its species, this eukaryote is ubiquitous in distribution. Some of the species survived well the Cryogenian glaciations and into the Ediacaran and the Cambrian (Jankauskas et al., 1989; Grey, 2005; Veis et al., 2006; Fig. 3).

Another eukaryotic microfossil, Valkyria borealis, certainly survived the Sturtian and Marinoan glaciations. The present finding of $V$. borealis is the first such finding outside its type area and is from a stratigraphic level separated from the previous record by a time lapse of $c a .155 \mathrm{Ma}$.

\section{Discussion}

Interpretation of the microfossil association from the Lublin Slope has a bearing on the discussion of how life survived the Snowball Earth glacial epochs by demonstrating that more species lived continuously into the late Ediacaran times, and by recognizing their modes of life and habitats.
The Snowball Earth hypothesis pictures the planet totally frozen for millions of years during several glacial episodes between ca. 720-635 Ma (within the Cryogenian Period), when continental and shelf ground ice sheets extended into low latitudes and oceanic circulation was disrupted (Hoffman et al., 1998). The sea ice covering the ocean caused its anoxia and blocked sun light for photosynthesis. As a result, biological productivity in the surface ocean ceased. The Earth's frozen stage was abruptly switched into greenhouse conditions due to the accumulation of carbon dioxide from subaerial volcanism as is depicted by precipitation of cap carbonates worldwide. In these harsh climatic and environmental conditions, very limited refugia for bacteria and simple eukaryotes were suggested to be in meltwater pools, ice cracks, open leads or hydrothermal veins (Hoffman et al., 1998; Hoffman and Schrag, 2002). Accordingly, the acclaimed worst catastrophe in history left the Earth almost lifeless because of extinction of the photosynthesising biota. The chain reaction initiated by blocking sun light energy for photosynthesis and depletion of oxygen in the ocean (or no ocean existing because it became frozen), eliminated primary producers and shortly after heterotrophic consumers. Almost miraculously, the postglacial diversity and complexity of life observed in the Ediacaran aroused abruptly as an aftermath of the Cryogenian environmental catastrophe.

The quality and robustness of microbial records previously known (Jankauskas et al., 1989; Schopf and Klein, 1992; Sepkoski and Schopf, 1992; Knoll, 1994; Vidal and Moczydłowska, 1997) have been largely neglected in this hibernal scenario, giving priority to geological data and their interpretations in the Snowball Earth hypothesis. Complemented by recent new evidence (Grey et al., 2003; Knoll, 2003; Corsetti et al., 2003, 2006; Moczydłowska, 2004, 2006; Grey, 2005; Olcott et al., 2005; Sergeev, 2006; Veis et al., 2006; Willman and Moczydłowska, 2007, 2008), and the present record, the fossils prove directly the relative richness of organisms that survived the Cryogenian glaciations.

The surviving microbiota, some studied here (Fig. 3), were not extremophiles that could exist in the suggested refugia such as near hot springs, cracks in the sea ice or around volcanoes. On the contrary, they are aerobic eukaryotes with morphologic complexity and probable intricate reproductive cycles (Butterfield, 2000; Moczydłowska, 2004, 2006; Xiao, 2004; Knoll et al., 2006), and prokaryotes living in communities and being specialized, like some cyanobacteria, in framing, supporting or constructing bacterial mats in a determined morphological and functional manner (Golubic, 1999a,b). Their life habitats were not extreme but normal shallow marine.

\section{Conclusions}

A new record of late Ediacaran microfossils, including prokaryotic cyanobacteria and eukaryotic leiosphaerids, enigmatic microfossil Valkyria borealis and some others of uncertain affinities, provides additional evidence of the existence of marine benthic and planktic microbiota that survived the Snowball Earth glaciations during the Cryogenian Period. The mode of life, nutrition, respiration and reproduction cycle of these microbiota and their natural habitats are well recognized and can be analyzed in the context of their environmental requirements and survival strategies with implications for the Snowball Earth hypothesis.

The Ediacaran age of the microfossil association, deriving from the Włodawa Formation in the Łopiennik IG-1 borehole in Poland, is biostratigraphically and numerically well defined and estimated at ca. $545 \mathrm{Ma}$.

All cyanobacteria described are benthic and associated with growth in bacterial mats, whereas leiosphaerids are planktic and 
Valkyria may likely be also planktic and/or facultative benthic. The occurrence of microfossils is in situ in shallow shelf siliciclastic sediments in which planktic species accumulated from a "marine snow", while benthic cyanobacteria were buried after being fragmented from the coastal bacterial mats and displaced by water currents over a very short distance.

The cyanobacteria were photoautotrophic, aerobic, reproduced asexually and lived in benthic communities as mat-builders or dwellers, and they required ample water and regular oxygen supply and sunlight for their metabolism. Such habitats must have been preserved and ecologically functional throughout the Cryogenian Period.

Leiosphaeridia crassa and $L$. minutissima from the association are interpreted to be marine chlorophyceans (and chlorococcaleans in case of the latter species), characterised by photosynthetic nutrition, aerobic respiration, having a sexual/asexual cycle of reproduction and planktic mode of life. As such, they needed welloxygenated open water habitats in the photic zone, and periodic access to the bottom sediment in order to survive the Cryogenian Period, as they certainly did.

The genus Valkyria, a complex taxon, appeared before the Sturtian glacial epoch and lasted to the end of the Ediacaran, as shown by the present finding for the first time outside the type area and at a stratigraphic level younger by some $155 \mathrm{Ma}$ than the previous record. It adds to the known record of morphologically distinctive eukaryotes such as Octoedryxium, Pterospermopsimorpha, Cymatiosphaeroides, Valeria, Simia, Trachyhystrichosphaera, Chuaria, Tawuia, and Grypania spiralis, whose ranges extend from Meso- or early Neoproterozoic into the Cryogenian and Ediacaran (Veis et al., 2006; Xiao and Kaufman, 2006; Grazhdankin and Nagovitsin, 2007).

An Earth System model with open ocean realms, ice-free shelves (at least seasonally) and access to the sea floor is obligatory for the Cryogenian Period to satisfy the life requirements of the biota, which evidently survived the period. Especially, the photosynthetic biota, which are at the base of the trophic web and their metabolic/ecologic requirements must have been sustained, not only to permit them to survive but also that they could support heterotrophs.

The model of the Slushball Earth by Hyde et al. (2000), or similar, postulating circum-equatorial areas of open water and access to a coastal zone with a sea floor substrate, would provide sufficiently robust environments for photosynthetic benthic cyanobacteria and pelagic phytoplankton and for early metazoans without any extreme adaptations.

\section{Acknowledgements}

I acknowledge funding by the Swedish Research Council (Vetenskapsrådet) through research grant $\mathrm{Nr}$ 621-2004-5316. I thank Kath Grey, Perth, for continuous and fruitful discussions and collaboration in search for microbes in Precambrian, which adds salt to the table. Sebastian Willman, Uppsala, Ph.D. student and a new adept in the field, helped with his fresh views and assistance in preparing graphics. Gary Wife, Evolutionary Biology Centre, Uppsala University, is acknowledged for image processing.

The study was a part of the presentation during the Snowball Earth 2006 Conference at Monte Verità, Ticino, Switzerland, that gave an excellent opportunity to exchange the views with colleagues involved in the IGCP project 512.

I thank the reviewers (Malcolm Walter and Axel Hofmann) for their constructive comments, which improved the manuscript, and Graham Budd for his independent reading of the manuscript.

\section{References}

Arouri, K., Greenwood, P.F., Walter, M.R., 2000. Biological affinities of Neoproterozoic acritarchs from Australia: microscopic and chemical characterisation. Organic Geochemistry 31, 75-89.

Aseeva, E.A., 1982. Novye vidy planktonnykh vodorosliy venda Volhyno-Podoli (New species of planktic algae from the Vendian of Volhyn-Podolia). Sistematika i evolutsya drevnikh rasteniy Ukrainy (Systematics and Evolution of Ancient Plants of Ukraine), Naukova Dumka, Kiev, 5-16 (in Russian).

Aseeva, E.A., 1983. Mikrofitofossili venda Ukrainy (The Vendian microphytofossils of Ukraine). In: Velikanov, V.A., Aseeva, E.A., Fedonkin, M.A. (Eds.), Vend Ukrainy (The Vendian of Ukraine). Naukova Dumka, Kiev, pp. 102-127 (in Russian).

Bold, H.C., Wynne, M.J., 1985. Introduction to the Algae. Structure and Reproduction. Prientice-Hall, Inc., Englewood Cliffs, New Jersey, 720 pp.

Butterfield, N.J., 2000. Bangiomorpha pubescens n. gen., n. sp.: implications for the evolution of sex, multicellularity and the Mesoporterozoic-Neoproterozoic radiation of eukaryotes. Paleobiology 26, 386-404.

Butterfield, N.J., 2004. A vaucheriacean alga from the middle Neoproterozoic of Spitsbergen: implications for the evolution of Proterozoic eukaryotes and the Cambrian explosion. Paleobiology 30, 231-252.

Butterfield, N.J., Chandler, F.W., 1992. Paleoenvironmental distribution of Proterozoic microfossils, with an example from the Agu Bay Formation, Baffin Island. Palaeontology 35, 943-957.

Butterfield, N.J., Knoll, A.H., Swett, K., 1994. Paleobiology of the Neoproterozoic Svanbergfjellet Formation, Spitsbergen. Fossils and Strata 34, 84.

Canfield, D.E., Poulton, S.W., Narbonne, G.M., 2007. Late-Neoproterozoic deep-ocean oxygenation and the rise of animal life. Science 315, 92-95.

Cocks, L.R.M., Torsvik, T.H., 2005. Baltica from the late Precambrian to midPalaeozoic times: the gain and loss of a terrane's identity. Earth-Science Reviews 72, 39-66.

Colbath, G.K., Grenfell, H.R., 1995. Review of biological affinities of Paleozoic acidresistant, organic-walled eukaryotic algal microfossils (including "acritarchs"). Review of Palaeobotany and Palynology 86, 287-314.

Compston, W., Sambridge, M.S., Reinfrank, R.F., Moczydłowska, M., Vidal, G., Claesson, S., 1995. Numerical ages of volcanic rocks and the earliest faunal zone within the Late Precambrian of east Poland. Journal of the Geological Society, London 152, 599-611.

Corsetti, F.A., Awramik, S.M., Pierce, D., 2003. A complex microbiota from snowball Earth times: microfossils from the Neoproterozoic Kingston Peak Formation, Death Valley, USA. Proceedings of the National Academy of Sciences of the United States of America 100, 4399-4404.

Corsetti, F.A., Olcott, A.N., Bakermans, C., 2006. The biotic response to Neoproterozoic snowball Earth, Palaeogeography, Palaeoclimatology. Palaeoecology 232, $114-130$.

Cotter, K.L., 1997. Neoproterozoic microfossils from the Officer Basin, Western Australia. Alcheringa 21, 247-270.

Downie, C., Sarjeant, W.A.S., 1963. On the interpretation and status of some hystrichosphere genera. Palaeontology 6, 83-96.

Eisenack, A., 1958. Tasmanites Newton 1975 und Leiosphaeridia n. gen. aus gattungen der Hystrichosphaeridea. Palaeontographica A 110, 1-19.

Falkowski, P.G., Knoll, A.H., 2007. Evolution of Primary Producers in the Sea. Academic Press, $441 \mathrm{pp}$.

Fensome, R.A., Williams, G.L., Sedley Barss, M., Freeman, J.M., Hill, J.M., 1990 Acritarchs and fossil prasinophytes: an index to genera, species and infraspecific taxa. American Association of Stratigraphic Palynologists Contributions Series Number 25, $771 \mathrm{pp}$.

Fike, D.A., Grotzinger, J.P., Pratt, L.M., Summons, R.E., 2006. Oxidation of the Ediacaran Ocean. Nature 444, 744-747.

Gehling, J.G., Narbonne, G.M., Anderson, M.M., 2000. The first named Ediacaran body fossil, Aspidella terranovica. Palaeontology 43, 427-456.

Geyer, G., Uchman, A., 1995. Ichnofossil assemblages from the Nama Group (Neoproterozoic-Lower Cambrian) in Namibia and the Proterozoic-Cambrian boundary problem revisited. In: Geyer, G., Landing, E. (Eds.), Morocco 95 The Lower-Middle Cambrian standard of Western Gondwana. Beringeria Special Issue 2, 173-202.

Glotzer, M., 2005. The molecular requirements for cytokinesis. Science 307, $1735-1739$.

Golubic, S., 1999a. Microbial mats of Abu Dhabi. In: Margulis, L., Olendzenski, L. (Eds.), Environmental Evolution. Effects of the Origin and Evolution of Life on Planet Earth. The MIT Press, Cambridge, Massachusetts, pp. 103-130.

Golubic, S., 1999b. Stromatolites of Shark Bay. In: Margulis, L., Olendzenski, L. (Eds.), Environmental Evolution. Effects of the Origin and Evolution of Life on Planet Earth. The MIT Press, Cambridge, Massachusetts, pp. 131-147.

Golubic, S., Hofmann, H.J., 1976. Comparison of Holocene and mid-Precambrian Entophysalidacea (Cyanophyta) in stromatolitic algal mats: cell division and degradation. Journal of Paleontology 50, 1074-1082.

Gradstein, F., Ogg, J., Smith, A. (Eds.), 2004. A Geologic Time Scale. Cambridge University Press, $589 \mathrm{pp}$.

Grazhdankin, D.V., Nagovitsin, K.E., 2007. Late Vendian Miaohe-type ecological assemblage of the East European Platform. Doklady Earth Sciences 417 $1183-1187$.

Grey, K., 2005. Ediacaran palynology of Australia. Memoir of the Association of Australasian Palaeontologists 31, 1-439.

Grey, K., Walter, M.R., Calver, C.R., 2003. Neoproterozoic biotic divesification: Snowball Earth or aftermath of the Acraman impact? Geology 31, 459-462. 
Hackett, J.D., Yoon, H.S., Butterfield, N.J., Sanderson, M.J., Bhattacharya, D., 2007. Plastid endosymbiosis: sources and timing of the major events. In: Falkowski, P.G., Knoll, A.H.(Eds.), Evolution of Primary Producers in the Sea. Academic Press, Amsterdam, pp. 109-132.

Hagenfeldt, S.E., 1989. Lower Cambrian acritarchs from the Baltic Depression and south central Sweden, taxonomy and biostratigraphy. Stockholm Contributions in Geology 41, 1-176.

Halverson, G.P., 2006. A Neoproterozoic chronology. In: Xiao, S., Kaufman, A.J. (Eds.), Neoproterozoic Geobiology and Paleobiology. Springer, pp. 231-271.

Hermann, T.N., 1974. Nakhodki massovykh skapleniy trikhomov v rifee (Findings of the mass occurrence of trichomes in Riphean). Mikrofitifossili proterozoya i rannego paleozoya SSSR (Microphytofossils of Proterozoic and Early Palaeozoic of the USSR). Nauka, Leningrad, pp. 6-10 (in Russian).

Hermann, T.N., 1990. Organic World Billion Years Ago. Nauka, Leningrad, 50 pp.

Hoffman, P.F., Kaufman, A.J., Halverson, G.P., Schrag, D.P., 1998. A Neoproterozoic snowball Earth. Science 281, 1342-1346.

Hoffman, P.F., Schrag, D.P., 2002. The snowball Earth hypothesis: testing the limits of global change. Terra Nova $14,129-155$

Hofmann, H.J., 1976. Precambrian microflora, Belcher Islands, Canada: significance and systematics. Journal of Paleontology 50, 1040-1073.

Hofmann, H.J., Jackson, G.D., 1994. Shale facies microfossils from the Proterozoic Bylot Supergroup, Baffin Island, Canada. Paleontological Society Memoir 37, 39.

Horodyski, R.J., Donaldson, J.A., 1980. Microfossils from the Middle Proterozoic Dismal Lake Group, Arctic Canada. Precambrian Research 11, 125-159.

Hyde, W.T., Crowley, T.J., Baum, S.K., Peltier, W.R., 2000. Neoproterozoic "snowball Earth" simulations with a coupled climate/ice-sheet model. Nature 405, 425-429.

Jankauskas, T.V., 1980. Novye vodorosli iz verkhnego rifeya Yuzhnogo Urala (New algae from the Upper Riphean of Southern Urals). Paleontologitsheskii Zhurnal 4, 107-113 (in Russian).

Jankauskas, T.V., 1982. Microfossili rifeya Yuzhnogo Urala (Riphean microfossils of the Southern Urals). In: Keller, B.M. (Ed.), Stratotip Rifeya. Paleontologiya i Paleomagnetizm (Stratotype of Riphean. Paleontology and Paleomagnetism). Nauka, Moscow, pp. 84-120 (in Russian).

Jankauskas, T.V., 1985. Rastitelnye mikrofossili Urala (Plant microfossils of the Urals). In: Sokolov, B.S., Ivanovkiy, A.B. (Eds.), Vendskaya sistema 1. Paleontologiya (Vendian System 1. Palaeontology). Nauka, Moscow, pp. 145-146.

Jankauskas, T.V., 1990. Plant microfossils of the Urals. In: Sokolov, B.S., Iwanowski, A.B. (Eds.), The Vendian System Paleontology, vol. 1. Springer-Verlag, Berlin, pp. $171-173$.

Jankauskas, T.V., Mikhailova, N.S., German, T.N., Segreyev, V.N., et al., 1989. Mikrofossili dokembriya SSSR (Precambrian microfossils of the USSR). Nauka, Leningrad, 191 pp. (in Russian).

Javaux, E.J., Knoll, A.H., Walter, M., 2004. TEM evidence for eukaryotic diversity in mid-Proterozoic oceans. Geobiology 2, 121-132.

Jenkins, G., McMenamin, M., Sohl, L., McKay, C.(Eds.), 2004. The Extreme Proterozoic: Geology, Geochemistry, and Climate. American Geophysical Union, Geophysical Monograph Series 146, 229 pp.

Kirjanov, V.V., 1968. Paleontologicheskie ostatki i stratigrafiya otlozheniy boltijskoy serii Volyno-Podoli (Palaeontological remains and stratigraphy of the Baltic Group deposits in Volhynia-Podolia). In: Paleontologiya i stratigrafiya nizhnego paleozoya Volyno-Podoli (Palaeontology and Stratigraphy of the Lower Palaeozoic in Volhynia-Podolia). Naukova Dumka, Kiev, pp. 5-25 (in Russian).

Knoll, A.H., 1994. Proterozoic and Early Cambrian protists: evidence for accelerating evolutionary tempo. Proceedings of the National Academy of Sciences of the United States of America 91, 6743-6750.

Knoll, A.H., 2003. Life on a Young Planet. Princeton University Press, Princeton and Oxford, $277 \mathrm{pp}$

Knoll, A.H., Golubic, S., 1979. Anatomy and taphonomy of a Precambrian algal stromatolite. Precambrian Research 10, 115-151.

Knoll, A.H., Swett, K., 1987. Micropalaeontology across the Precambrian-Cambrian boundary in Spitsbergen. Journal of Paleontology 61, 898-926.

Knoll, A.H., Swett, K., Mark, J., 1991. Paleobiology of a Neoproterozoic tidal flat/lagoonal complex: the Draken Conglomerate Formation, Spitsbergen. Journal of Paleontology 65, 531-570.

Knoll, A.H., Javaux, E.J., Hewitt, D., Cohen, P., 2006. Eukaryotic organisms in Proterozoic oceans. Philosophical Transactions of the Royal Society, B 361, 1023-1038.

Kolosov, P.N., 1982. Verkhnedokembriyskie paleontologicheskie ostatki Sibirskoy platformy (Upper Precambrian Palaeontological Remains of the Siberian Platform). Nauka, Moscow, 96 pp. (in Russian).

Kolosov, P.N., 1984. Pozdnedokembriyskie mikroorganizmy vostoka Sibirskoy platformy. (Late Precambrian Microorganisms of the Eastern Siberian Platform). Yakutian Division of the AN SSSR, Yakutsk, 84 pp. (in Russian).

Korkutis, V., 1981. Late Precambrian and Early Cambrian in the East European Platform. Precambrian Research 15, 75-94.

Landing, E., 1994. Precambrian-Cambrian boundary global stratotype ratified and a new perspective on Cambrian time. Geology 22, 179-182.

Lendzion, K., 1977. First gastropod fauna from the Klimontovian Stage (Lower Cambrian) of the South-Eastern Poland. Kwartalnik Geologiczny 21, 239-243.

Lendzion, K., 1983. Rozwój kambryjskich osadów platformowych Polski. Prace Instytutu Geologicznego 105, 55 pp.

Lendzion, K., Paczesna, J., Moczydłowska-Vidal, M., 2008. Profil litologicznostratygraficzny według rdzeni i pomiarów geofizycznych. Kambr. In: Paczesna,
J. (Ed.), Łopiennik IG 1. Profile Głebokich Otworów Wiertniczych Panstwowego Instytutu Geologicznego, vol. 123, pp. 51-58.

Mankiewicz, C., 1992. Proterozoic and Early Cambrian calcareous algae. In: Schopf, J.W., Klein, C. (Eds.), The Proterozoic Biosphere. A Multidisciplinary Study. Cambridge University Press, pp. 981-998.

Mansfeld, J., Claesson, S., Sundblad, K., Motuza, G., Moczydłowska, M., Reinfrank, R., 1993. The Precambrian crust southeast of the Baltic Sea-possible correlation with the Fennoscandian Shield. Terra abstracts 1, EUG VII Strasbourg, April 4-8, p. 318.

Margulis, L., Corliss, J.O., Melkonian, M., Chapman, D.J. (Eds.), 1989. Handbook of Protoctista. Jones and Bartlett Publishers, Boston, $914 \mathrm{pp}$.

Marshall, C.P., Javaux, E.J., Knoll, A.H., Walter, M.R., 2005. Combined micro-Fourier transform infrared (FTIR) spectroscopy and micro-Raman spectroscopy of Proterozoic acritarchs: a new approach to Palaeobiology. Precambrian Research 138, 208-224.

Marshall, C.P., Carter, E.A., Leuko, S., Javaux, E.J., 2006. Vibrational spectroscopy of extant and fossil microbes: relevance for the astrobiological exploration of Mars. Vibrational Spectroscopy 41, 182-189.

Melkonian, M., 1989. Chlorophyta. In: Margulis, L., Corliss, J.O., Melkonian, M., Chapman, D.J. (Eds.), Handbook of Protoctista. Jones and Bartlett Publishers, Boston, pp. 597-616.

Mendelson, C.V., Schopf, J.W., 1982. Proterozoic microfossils from the Sukhaya Tunguska, Shorikha, and Yudoma Formations of the Siberian Platform, USSR. Journal of Paleontology 56, 42-83.

Mendelson, C.V., Schopf, J.W., 1992. Proterozoic and selected Early Cambrian microfosslis and microfossil-like objects. In: Schopf, J.W., Klein, C. (Eds.), The Proterozoic Biosphere. A Multidisciplinary Study. Cambridge University Press, pp. 865-951.

Moczydłowska, M., 1988. Thermal alteration of the organic matter around the Precambrian-Cambrian transition in the Lublin Slope of the East European Platform in Poland. Geologiska Föreningens i Stockholm Förhandlingar 110, 351-361.

Moczydłowska, M., 1991. Acritarch biostratigraphy of the Lower Cambrian and the Precambrian-Cambrian boundary in southeastern Poland. Fossils and Strata 29, $127 \mathrm{pp}$.

Moczydłowska, M., 1999. The Lower-Middle Cambrian boundary recognized by acritarchs in Baltica and at the margin of Gondwana. Bolletino della Societa Paleontologica Italiana $38(2-3), 207-225$.

Moczydłowska, M., 2002. Early Cambrian phytoplankton diversification and appearance of trilobites in the Swedish Caledonides with implications for coupled evolutionary events between primary producers and consumers. Lethaia 35 , 191-214.

Moczydłowska, M., 2004. Neoproterozoic microbiota-adaptations and survival of severe environmental disturbances. In: Proceedings of the 11th International Palynological Congress, Granada, Spain, Polen, July 4-9, vol. 14, p. 129.

Moczydłowska, M., 2006. The Ediacaran phytoplankton and cyanobacteria-a recovery after snowball Earth conditions. In: Snowball Earth 2006 Conference, Monte Verità, Ticino, Switzerland, July 16-21, p. 76 (Abstracts).

Moczydłowska, M., Vidal, G., 1986. Lower Cambrian acritarch zonation in southern Scandinavia and southeastern Poland. Geologiska Föreningens i Stockholm Förhandlingar 108, 201-223.

Moczydłowska, M., Zang, W.-L., 2006. The Early Cambrian acritarch Skiagia and its significance for global correlation. Palaeoworld 15, 328-347.

Muir, M. 1976. Proterozoic microfossils from the Amelia Dolomite, McArthur Basin, Northern Territory. Alcheringa 1, 143-158.

Naumova, S.N., 1949. Obshchaya morfologicheskaya kharakteristika spor nizhnego kembriya (The general morphological characteristic of the Lower Cambrian spores). Izvestiya AN SSSR, Seriya Geologicheskaya 4, 49-56 (in Russian).

Olcott, A.N., Sessions, A.L., Corsetti, F.A., Kaufman, A.J., Flavio de Oliviera, T., 2005. Biomarker evidence for photosynthesis during Neoproterozoic glaciation. Sciencexpress, www.sciencexpress.org/29 September 2005/Page 1/10.1126/science.1115769.

Paczesna, J., 1986. Upper Vendian and Lower Cambrian ichnocoenoses of Lublin region. Biuletyn Instytutu Geologicznego 355, 31-47.

Paczesna, J., 1996. The Vendian and Cambrian ichnocoenoses from the Polish part of the East European Platform. Prace Panstwowego Instytutu Geologicznego 152, $77 \mathrm{pp}$.

Paczesna, J., Poprawa, P., 2005. Eustatic versus tectonic control on development of the Neproterozoic and Cambrian stratigraphic sequences of the Lublin-Podlasie Basin (SW margin of Baltica). Geosciences Journal 9, 117-127.

Paczesna, J., Krzeminska, E., Moczydłowska-Vidal, M., 2008. Profil litologicznostratygraficzny według rdzeni i pomiarów geofizycznych. Ediakar. In: Paczesna, J. (Ed.), Łopiennik IG 1. Profile Głebokich Otworów Wiertniczych Panstwowego Instytutu Geologicznego, vol. 123, pp. 58-62.

Paskevicienè, L.T., 1980. Akritarkhi pogranichnykh otlozheniy venda i kembriya zapada Vostochno-Evropeyskoy platformy (Aritarchs from the Vendian and Cambrian boundary strata of the western part of the East European Platform). Nauka, Moscow, 60 pp.

Peterson, K.J., Butterfield, N.J., 2005. Origin of the Eumetazoa: testing ecological predictions of molecular clocks against the Proterozoic fossil record. Proceedings of the National Academy of Sciences of the United States of America 102, 9547-9552.

Poprawa, P., Paczesna, J., 2002. Rozwój ryftu w póznym neoproterozoiku-wczesnym paleozoiku na lubelsko-podlaskim skłonie kratonu wschodnioeuropejskiegoanaliza subsydencji i zapisu facjalnego. Przeglad Geologiczny 50, 49-63. 
Pyatiletov, V.G., 1979. O nakhodkakh sinezelenykh vodorosley v yudomskikh otlozhenyakh Yakuti (vend) (Findings of the blue-green algae in the Yudomian deposits of Yakutia (Vendian). Doklady AN SSSR 249, 714-716 (in Russian).

Ragozina, A.L., Sivertseva, I.A., 1990. In: Sokolov, B.S., Iwanowski, A.B. (Eds.), The Vendian System Paleontology, vol. 1. Springer-Verlag, Berlin, pp. 165-171.

Schopf, J.W., 1968. Microflora of the Bitter Springs Formation, Late Precambrian, Central Australia. Journal of Paleontology 42, 651-688.

Schopf, J.W., 1992. Atlas of representative Proterozoic microfossils. Informal revised classification of Proterozoic microfossils. In: Schopf, J.W., Klein, C. (Eds.), The Proterozoic Biosphere: A Multidisciplinary Study. Cambridge University Press, pp. $1055-1118,1119-1168$.

Schopf, J.W., 1999. Cradle of Life. Princeton University Press, Princeton, New Jersey, 367 pp.

Schopf, J.W., Klein, C. (Eds.), 1992. The Proterozoic Biosphere: A Multidisciplinary Study. Cambridge University Press, 1338 pp.

Schopf, J.W., Walter, M.R., 1982. Origin and early evolution of cyanobacteria: the geological evidence. In: Carr, N.G., Whitton, B.A. (Eds.), The Biology of Cyanobacteria Blackwell Scientific Publications, Oxford, pp. 543-564.

Seong-Joo, L., Golubic, S., 1998. Multi-trichomous cyanobacterial microfossis from the Mesoproterozoic Gaoyuzhung Formation, China: paleoecological and taxonomic implications. Lethaia 31, 169-184.

Seong-Joo, L., Golubic, S., 1999. Microfossils populations in the context of synsedimentary micrite deposition and acicular carbonate precipitation: Mesoproterozoic Gaoyuzhung Formation, China. Precambrian Research 96, $183-208$.

Seong-Joo, L., Golubic, S., Zhang, Y., 1999. Paleoenvironmental distribution of silicified microfossil assemblages from Gaoyuzhuang Formation, North China. Acta Micropalaeontologica Sinica 16, 237-258.

Sepkoski Jr., J.J., Schopf, J.W., 1992. Biotic diversity and rates of evolution during Proterozoic and earliest Phanerozoic time. In: Schopf, J.W., Klein, C. (Eds.), The Proterozoic Biosphere: A Multidisciplinary Study. Cambridge University Press, pp. 521-566.

Sergeev, V.N., 2006. Okremnennye mikrofossili dokembriya: priroda, klassifikatsiya i biostratigraphitcheskoe znatchenie (Precambrian Microfossils in Cherts: thei Paleobiology, Classification and Biostratigraphic Usefulness). GEOS, Moscow, 280 pp. (in Russian).

Sergeev, V.N., Knoll, A.H., Grotzinger, G.P., 1995. Paleobiology of the Mesoproterozoic Billyakh group, Anabar Uplift, Northern Siberia. Paleontological Society Memoir 39, $37 \mathrm{pp}$.

Shepeleva, E.D., 1960. Hakhodka sine-zelenykh vodorosley v nizhnekembriyskikh otlozheniyakh Leningradskoy oblasti. (Finding of blue-green algae in the Lowe Cambrian strata of the Leningrad District). In: Problemy neftiyanoy geologii voprosy metodiki laboratornykh issledovaniy. (Problems of the oil geology and issues of the laboratory method studies), pp. 170-172 (in Russian).

Simpson, G.G., 1944. Tempo and Mode in Evolution. Columbia University Press, New York, $237 \mathrm{pp}$.

Sogin, M.L 1994. The origin of eukaryotes and evolution into major kingdoms. In: Bengtson, S. (Ed.), Early Life on Earth, Nobel Symposium No. 84. Columbia University Press, New York, pp. 181-192.

Strauss, H., Vidal, G., Moczydłowska, M., Paczesna, J., 1997. Carbon isotope geochemistry and palaeontology of Neoproterozoic to early Cambrian siliciclastic successions in the East European Platform, Poland. Geological Magazine 134, $1-16$.

Talyzina, N.M., Moczydłowska, M., 2000. Morphology and ultrastructural studies of some acritarchs from the Lower Cambrian Lükati Formation, Estonia. Review of Palaeobotany and Palynology 112, 1-21.

Tappan, H., 1980. The Paleobiology of Plant Protists. W.H. Freeman, San Fransisco, $1028 \mathrm{pp}$.

Timofeev, B.V., Hermann, T.H., 1976. Verkhnerifeyskaya flora r. Miroedikhi (Uppe Riphean flora of the River Miroedikha). In: Timofeev, B.V., Hermann, T.H. Mikhailova, N.S. (Eds.), Mikrofitofossili dokembriya, kembriya i ordovika (Microphytofossils of the Precambrian, Cambrian and Ordovician). Nauka, Leningrad, pp. 29-53 (in Russian).

Timofeev, B.V., Hermann, T.N., 1979. Dokembriyskaya mikrobiota Lakhandinskoy svity (Precambrian microbiota of the Lakhanda Formation). In: Sokolov, B.S. (Ed.), Paleontologiya dokembriya I rannego kembriya (Precambrian and early Cambrian palaeontology). Nauka, Moscow, pp. 137-147 (in Russian).

Timofeev, B.V., Hermann, T.H., Mikhailova, N.S. (Eds.), 1976. Mikrofitofossili dokembriya, kembriya i ordovika (Microphytofossils of the Precambrian, Cambrian and Ordovician). Nauka, Leningrad, 106 pp. (in Russian).

Torsvik, T.H., 2003. Perspectives-The Rodinia Jigsaw Puzzle. Science 300 1379-1381.

Torsvik, T.H., Smethurst, M.A., Meert, J.G., et al., 1996. Continental break-up and collision in the Neoproterozoic and Paleozoic-a tale of Baltica and Laurentia. Earth Science Reviews 40, 229-258.

Traverse, A., 2007. Paleopalynology. Springer, Dordrecht, 813 pp.

Turner, R.E., 1984. Acritarchs from the type area of the Ordovician Caradoc Series, Shropshire, England. Palaeontographica Abt. B 190, 87-157.
Tynni, R, Donner, J. 1980. A microfossil and sedimentation study of the Late Precambrian formation of Hailuoto, Finland. Geologian Tutkimusesus (Finland) Bulletin $311,1-27$

Veis, A.F., Vorobeva, N.G., Golubkova, E.Yu., 2006. The early Vendian microfossils first found in the Russian Plate: taxonomic composition and biostratigraphic significance. Stratigraphy and Geological Correlation 14 (4), 368-385 (Nauka/Interperiodica, Moscow) (Original Russian Text: Veis, A.F., Vorob'eva, N.G., Golubkova, E.Yu., 2006. Published in Stratigrafiya. Geologicheskaya Korrelyatsiya 14 (4), pp. $28-46$.).

Vickers-Rich, P., Komarower, P., et al., 2007. The Rise and Fall of the Ediacaran Biota. Geological Society, London, Special Publications 286, 275 pp.

Vidal, G., 1994. Early ecosystems: limitations imposed by the fossil record. In: Bengtson, S. (Ed.), Early Life on Earth, Nobel Symposium No. 84. Columbia University Press, New York, pp. 298-311.

Vidal, G., Ford, T., 1985. Microbiotas from the late Proterozoic Chuar Group (northern Arizona) and Uinta Mountain Group (Utah) and their chronostratigraphic implications. Precambrian Research 28, 349-489.

Vidal, G., Moczydłowska, M., 1995. The Neoproterozoic of Baltica-stratigraphy, palaeobiology and general geological evolution. Precambrian Research 73 197-216.

Vidal, G., Moczydłowska, M., 1997. Biodiversity, speciation and extinction trends of Proterozoic and Cambrian phytoplankton. Paleobiology 23 230-246.

Vidal, G., Palacios, T., Moczydłowska, M., Gubanov, A.P., 1999. Age constraints from small shelly fossils on the early Cambrian terminal Cadomian Phase in Iberia. GFF, The Geological Society of Sweden 121, 137-143.

Volkova, N.A., 1968. Akritarkhi dokembrijskikh i nizhnekembrijskikh otlozhenij Estonii (Acritarchs from the Precambrian and Cambrian deposits of Estonia). In Volkova, N.A., Zhuravleva, Z.A., Zabrodin, V.E., Klinger, B.Sh. (Eds.), Problematiki pogranichnykh sloev rifeja i kembrija Russkoj platformy, Urala i Kazakhstan (Problematics of Riphean and Cambrian layers of the Russian Platform, Urals and Kazakhstan). Nauka, Moscow, pp. 8-36 (in Russian).

Volkova, N.A., Kiryanov, V.V., Piscun, L.V., Pashkyavichene, L.T., Jankauskas, T.V. 1979. Rastitelnye mikrofossili (Microflora). In: Keller, B.M., Rozanov, A.Yu. (Eds.) Paleontologija verkhnedokembrijskikh i kembrijskikh otlozhenij VostochnoEvropejskoj platformy (Upper Precambrian and Cambrian palaeontology of the East-European Platform). Nauka, Moscow, pp. 4-38 (in Russian).

Whitton, B.A., Potts, M., 1982. Marine Littoral. In: Carr, N.G., Whitton, B.A. (Eds.), The Biology of Cyanobacteria. Blackwell Scientific Publications, Oxford, pp. 515-542.

Willman, S., Moczydłowska, M., 2007. Wall ultrastructure of an Ediacaran acritarch from the Oficer Basin, Australia. Lethaia 40, 111-123.

Willman, S., Moczydłowska, M., 2008. Ediacaran acritarch biota from the Giles 1 drillhole, Officer Basin, Australia, and its potential for biostratigraphic correlation. Precambrian Research 162, 498-530.

Woese, C.R., Kandler, O., Whellis, M.L., 1990. Towards a natural system of organisms: proposal for the domains Archaea, Bacteria, and Eucarya. Proceedings of the National Academy of Sciences of the United States of America 87, 4576-4579.

Xiao, S., 2004. Neoproterozoic glaciations and the fossil record. In: Jenkins, G McMenamin, M., Sohl, L., McKay, C. (Eds.), The Extreme Proterozoic: Geology, Geochemistry, and Climate. American Geophysical Union, Geophysical Monograph Series 146, pp. 199-214.

Xiao, S., Kaufman, A.J. (Eds.), 2006. Neoproterozoic Geobiology and Paleobiology. Topics in Geobiology. Springer, 300 pp.

Xing, Y., Liu, K., Luo, Q., Wang, Z., Yan, Y., Ding, L., Yin, C., Gao, L., 1985. Micropalaeophyta. In: Xing, Y., Duan, C., Liang, Y., Cao, R., et al. (Eds.), Late Precambrian Palaeontology of China. Geological Memoir Serie 2, no 2, Geological Publishing House, Beijing, pp. 7-67 (in Chinese).

Yin, L., 1987. Microbiotas of latest Precambrian sequences in China. In: Nanjing Institute of Geology and Palaeontology, Stratigraphy and Palaeontology of Systemic Boundaries in China, Precambrian-Cambrian Boundary, vol. 1. Nanjing University Publishing House, Nanjing, pp. 415-494.

Yin, L., 1991. Ecological history of Doushatuo period in Yangtze Gorge district. In: Jin, Y., Wang, J., Xu, S. (Eds.), Palaeoecology of China, vol. 1. Nanjing University Press, Nanjing, pp. 1-10.

Zang, W., 2001. Acritarchs. In: Alexander, E.M., Jago, J.B., Rozanov, A.Yu., Zhuravlev, A.Yu. (Eds.), The Cambrian Biostratigraphy of the Stansbury Basin, South Australia. IAPC Nauka, Moscow, pp. 74-85.

Zang, W., Moczydłowska, M., Jago, J.B., 2007. Lower Cambrian acritarch assemblage zones in South Australia and global correlation. Memoirs of the Association of Australasien Palaeontologsts 33, 141-177.

Zang, W.-L., Walter, M.R., 1992. Late Proterozoic and Early Cambrian microfossils and biostratigraphy, northern Anhui and Jiangsu, central eastern China. Precambrian Research 57, 243-323.

Zhang, Y., 1981. Eucaryotic unicellular microfosiils in the mid.Proterozoic Wumishan Formation (Sinian System) from the western Hopei Province, China. Journal of Paleontology 55, 485-506.

Zhang, Z., 1981. A new Oscillatoriaceae-like filamentous microfossils from the Sinian (late Precambrian) of western Hubei province, China. Geological Magazine 118 , 201-216. 